NBER WORKING PAPER SERIES

\title{
CAN FREE ENTRY BE INEFFICIENT? \\ FIXED COMMISSIONS AND SOCIAL WASTE IN THE REAL ESTATE INDUSTRY
}

\author{
Chang-Tai Hsieh \\ Enrico Moretti \\ Working Paper 9208 \\ http://www.nber.org/papers/w9208
NATIONAL BUREAU OF ECONOMIC RESEARCH
1050 Massachusetts Avenue
Cambridge, MA 02138
September 2002

We thank Ben Bernanke, David Card, Angus Deaton, Harold Demsetz, William Easterly, Ray Fisman, Gene Grossman, Karla Hoff, Peter Klenow, Phillip Leslie, Steve Levitt, Darren Lubotsky, Chris Redfearn, Scott Susin, John Wallis, and a referee for useful comments. We gratefully acknowledge partial financial support from the Center for Economic Policy Studies at Princeton University and the Academic Senate at UCLA. Hsieh worked on parts of this project while visiting the World Bank's Development Research Group, which he thanks for its hospitality. This paper previously circulated under the title "Uncovering Rent-Seeking and Social Waste: A Parable from the Real Estate Market." The views expressed herein are those of the authors and not necessarily those of the National Bureau of Economic Research.

(C) 2002 by Chang-Tai Hsieh and Enrico Moretti. All rights reserved. Short sections of text, not to exceed two paragraphs, may be quoted without explicit permission provided that full credit, including $\odot$ notice, is given to the source. 
Can Free Entry be Inefficient? Fixed Commissions and Social Waste in the Real Estate Industry Chang-Tai Hsieh and Enrico Moretti

NBER Working Paper No. 9208

September 2002

JEL No. J0, J4, L0

\begin{abstract}
Real estate agents in the US typically charge a 6 percent commission, regardless of the price of the house sold. As a consequence, the commission fee from selling a house will differ dramatically across cities depending on the average price of housing, although the effort necessary to match buyers and sellers may not be that different. We use a simple economic model and crosscity data to measure the effect of the fixed commission rate on market entry by real-estate agents. We show that if the commission rate does not vary and if there are low barriers to entry to the realestate brokerage business, the entry of real-estate agents into cities with high housing prices is socially inefficient. Consistent with our model, we find that when the average price of land in a city increases, (1) the fraction of real-estate brokers in a city increases; (2) the productivity of an average real-estate agent (houses sold per hour worked) falls; and (3) the real wage of a typical real-estate agent remains unchanged. We can not completely rule out the alternative explanation that these results reflect unmeasured differences in the quality of broker services. However, we present evidence that as the average price of housing in a city increases, there is only a small increase in the amount of time a buyer spends searching for a house, and the average time a house for sale stays on the market falls.
\end{abstract}

Chang-Tai Hsieh

Woodrow Wilson School

411 Robertson Hall

Princeton University

Princeton, NJ 08544

and NBER

chsieh@princeton.edu
Enrico Moretti Dept. of Economics, UCLA 405 Hilgard Ave. Los Angeles CA 90095-1477 and NBER email:moretti@ucla.edu 


\section{Introduction}

There is a widespread view that barriers to entry of new businesses are harmful, and that society would benefit from the removal of such barriers. Yet, it has also long been known that under certain conditions, free entry may actually be socially wasteful. ${ }^{1}$ The basic idea is that while the competition due to new entrants may lower prices, entrants also steal business from existing firms, and this latter effect could result in a socially inefficient over-spreading of output. The net gain from market entry thus depend on whether the price competition effect outweights the business stealing effect.

Yet, despite the possibility that market entry may be socially inefficient, there is little empirical work that measures the net social gains from market entry. The only work that we are aware of is Berry and Waldfogel's (1999, 2001) work on radio stations in the US. In this paper, we fill this gap by measuring the effect of entry in the U.S. residential real estate brokerage market. Two characteristics of the real-estate industry make it particularly interesting. First, there appears to be few barriers to entry in the industry. Second, in the period under consideration in this paper, the brokerage commission paid to the real-estate agents handling the sale of a house is almost always stated as a fixed 6 percent of the selling price of the house. What is particularly surprising about the apparent uniformity of the commission rate is that it implies that a real estate agent's commission from selling a house will differ dramatically depending on the price of the house, although the effort necessary to sell an expensive house may not be much different from that required to sell a cheaper home.

The main argument of this paper is that if in fact commission rates are fixed, then the absence of barriers to entry results in socially wasteful entry by real-estate agents in cities with high housing costs. Consider, for example, two cities - Boston and Minneapolis - that are similar in most dimensions except in the cost of housing. In 1990, the price of a typical house in Boston was roughly twice than in Minneapolis. ${ }^{2}$ With a fixed commission rate, the brokerage

\footnotetext{
${ }^{1}$ See Spence (1976a,b), Dixit and Stiglitz (1977), and Mankiw and Whinston (1986).

${ }^{2}$ According to the 1990 Census, the average price of residential housing was $\$ 216,231$ in Boston and $\$ 100,504$
} 
fee from selling a typical house in Boston was therefore twice that of a similar transaction in Minneapolis. If this is all there is to the story, real-estate agents in Boston would simply earn twice as much as their counterparts in Minneapolis. Real estate commissions would simply be a transfer from home-sellers and home-buyers to real-estate agents, and the deadweight loss from the fixed commission in Boston would probably be small, especially if the demand for real estate transactions is relatively price inelastic.

However, because there is relatively free entry into the real-estate business, an average realestate agent in Boston does not earn twice as much as an agent in Minneapolis. Because the commission from selling a typical house is twice as high in Boston than in Minneapolis, there are more real estate agents in Boston seeking these high commissions, although the total number of homes sold each year is actually larger in Minneapolis. Consequently, the average real estate agent in Minneapolis is much more productive than a typical agent in Boston, selling 6.6 houses each year in Minneapolis as compared to an average 3.3 houses a year in Boston. ${ }^{3}$

One could still argue that there is something fundamentally different between Boston and Minneapolis, that the effort necessary to sell a house in Boston is simply twice the effort necessary in Minneapolis. Perhaps the dense urban structure or the older age of dwellings in Boston makes it harder for brokers to sell houses, or perhaps descendants of Irish Catholics are more finicky about their housing than descendants of Germans and Scandinavians. However, it has not always taken twice as many real-estate agents to sell a house in Boston than in Minneapolis. Although the productivity of real-estate agents in Minneapolis was twice that in Boston in 1990, the difference was much smaller in 1980. In 1980, a typical real-estate agent in Boston sold 6 houses while her counterpart in Minneapolis sold 7 homes. What accounts for this change? From 1980 to 1990, housing prices doubled in Boston, while the average price of housing in Minneapolis remained unchanged. Since the commission rate is fixed, the commission from selling a house in Boston increased from 1980 to 1990, and thus attracted many people into the real-estate business

in Minneapolis.

${ }^{3}$ We see a similar productivity gap when we measure productivity as houses sold per hour worked: 0.0018 in Boston; 0.0036 in Minneapolis. 
in Boston seeking to earn these fees. By 1990, the number of real-estate agents in Boston had roughly doubled. And since the number of houses sold in Boston in 1990 had roughly remained unchanged, the productivity of an average real-estate agent in Boston in 1990 had fallen to almost half of what it was in 1980 .

The tragedy of this outcome is that despite the fact that home sellers in Boston pay twice as much to real-estate agents than in Minneapolis, real-estate agents in Boston are no better off than in Minneapolis, nor are they better off than their counterparts in 1980. The higher commissions in Boston are simply dissipated, wasted through the entry of real-estate agents seeking to earn these higher commissions, agents who could be profitably engaged in other activities.

In short, this comparison of Boston and Minneapolis suggests we look for the following three pieces of indirect evidence of socially wasteful entry by real-estate agents. Specifically, if commission rates are fixed and if real-estate agents dissipate higher commissions in high housing cost cities through entry, in cities with high housing prices, we should see: (1) more real-estate agents (relative to the city's labor force), (2) lower productivity (sales per agent or sales per hours worked), and (3) real-wages of real-estate agents that are no higher than in low housing cost cities.

In this paper, we find strong support for all three conjectures, both in a cross-section of 282 cities, and also when considering changes across these cities from 1980 to 1990. These results also hold true when we account for part-time real-estate agents. As a preview of our empirical evidence, consider the scatter-plot of the change in the log productivity of an average real-estate agent in a city from 1980 to 1990 against the change in the average log price of housing (Figure 1). This figure suggests that a one percent increase in average housing prices in a city results in a 0.7 percent decline in brokers' productivity, which we interpret as indicating that 70 percent of the higher commissions in high housing cost cities translate into social waste. However, an alternative explanation is that the higher commission in high housing cost cities may reflect the possibility that a broker has to spend more time matching buyers and sellers in such cities. For example, expensive houses may have idiosyncratic features. And even when differences in 
housing prices are entirely due to the price of land (rather than housing quality), home-buyers in expensive cities may take more time searching and visit more houses before making a decision. Therefore, the correlation between housing prices and the productivity of realtors may reflect differences in the quality of the service provided by realtors.

Although we can not completely rule out this interpretation, bear in mind that the evidence presented in Figure 1 considers changes over time, which abstract from permanent characteristics of cities that might also reflect the difficulty of matching buyers and sellers in a given city. In addition, we also provide four pieces of evidence that are inconsistent with this interpretation. First, we condition on measures of changes in the quality of housing such as changes in size, age, and dwelling structure. Second, we use two indices of housing prices that are based on repeated sales of the same property as instruments for changes in the price of housing in a city. These instrumental variable estimates are entirely driven by changes in the price of land, and are therefore robust to changes in unobservable characteristics of housing. Our results do not change when we introduce these two modifications. Third, we use data on vacancies to show that increases in housing prices in a city are associated with decreases in the average time houses for sale remain on the market. This suggests that when housing prices increase, realtors find it easier, not harder, to match buyers and sellers. ${ }^{4}$ Finally, we show that although the average number of houses visited by home buyers and the amount of time a home buyer spends searching for a house rises with housing prices, this correlation is small and can only explain less than a fifth of the documented correlation between productivity and housing prices.

We want to make clear that our argument is based on the assumption that commission rates are relatively fixed across cities. While our empirical evidence suggests that this was the case in the years we examine in this paper (1980 and 1990), there is some anecdotal evidence that in recent years, the internet may have made it possible for discount brokers to emerge. In turn, this may be putting downward pressure on commission rates. Clearly, if commission rates are

\footnotetext{
${ }^{4}$ The extreme example of this phenomenon is the housing market in Silicon Valley in the late 1990s, where houses were sold only hours after they were listed.
} 
in fact lower in high housing cost cities today, our hypothesis is that we would not observe the correlation between the productivity of real estate brokers and the price of housing in 1980 and 1990 that we document in this paper. ${ }^{5}$

The paper proceeds as follows. Section 2 presents evidence that suggests that commission rates are invariant to the price of housing. Section 3 presents anecdotal evidence on what realestate agents do and uses a simple theoretical framework to analyze the extent to which higher commission rates in high housing cost cities are dissipated by market entry. In Section 4, we present the empirical evidence. Section 5 concludes.

\section{The Real-Estate Brokerage Industry}

There are two striking empirical facts about the real-estate brokerage industry. First, an important aspect of the market for real-estate brokers is the absence of significant barriers to entry. The exam to obtain a license is the only barrier, and the requirements to pass the exam are limited. ${ }^{6}$ Moreover, at any point in time there is a large number of licensed but inactive brokers who are presumably ready to become active when it is profitable for them to do so. Table A1 presents the number of active and inactive licensed brokers in each state. As can be seen, an average 20 percent of licensed brokers are inactive.

A second striking empirical fact about real-estate brokerage services in the 1980s is that most commission rates appear to be fixed at 6 or 7 percent, regardless of whether the house sells for half a million dollars or for a hundred thousand dollars, or whether a house is more or less easy to sell. The uniformity of commission rates is well established in the real estate

\footnotetext{
${ }^{5}$ We use the terms broker and agent interchangeably in most of the paper. However, the broker is the supervisor (and often the owner of the real-estate firm) and the agent is the broker's employee. Most states require a separate license for brokers, and brokers typically need to have some experience as an agent to qualify as a broker. For most of the analysis, we will disregard this distinction, but in Section 4.2, we provide some evidence that the distinction between brokers and agents does not matter empirically.

${ }^{6}$ The annual issues of the "Digest of Real Estate License Laws" provide detailed data on the licensing requirements in each state.
} 
literature. $^{7}$ In fact, this lack of variation in commission rates was a major factor behind the Federal Trade Commission's (FTC) decision to investigate the real-estate brokerage industry for possible antitrust law violations in the early 1980s.

Specifically, the FTC's report provides three pieces of evidence that commission rates are remarkably uniform. The first piece of evidence, shown in the top panel in Figure 2, is from a nationally representative survey of 934 home-sellers conducted by the FTC in 1979 and $1980 .^{8}$ A second piece of evidence, shown in the bottom panel in Figure 2, comes from data compiled from the actual settlement documents of 5,000 home sales from all fifty states in $1979 .{ }^{9}$ Finally, Figure 3 presents the distribution of commission rates from a random sample of listings from the Multiple Listing Services (MLS) in Boston, Los Angeles, Minneapolis, and Seattle in 1978 and 1979. ${ }^{10}$ All three figures indicate that the majority of real estate agents get paid a commission rate of 6 or 7 percent.

A limitation with this evidence is that they are all from the late 1970s and early 1980s, and it is possible that commission rates are now more closely aligned with the actual time that realtors spend matching buyers and sellers. ${ }^{11}$ As we will discuss in detail later in the paper, our empirical analysis covers the years 1980 and 1990, and we do not have evidence comparable to that collected by the FTC on whether commission rates were still fixed at 6 percent after 1980. The only systematic evidence we have is from the Consumer Expenditure Survey (CEX) from 1980 to 1998. From the sample of families surveyed by the CEX who report having paid a commission to a realtor, Figure 4 presents a scatter plot of the commission rate and the price

\footnotetext{
${ }^{7}$ Examples of papers dealing with uniform commission rates include, but are by no means limited to, Carney (1981), Crockett (1982), Owen (1977), Miceli (1992), Turnbull (1996), Wachter (1987), Williams (1998), Arnold (1992), Goolsby and Childs (1989). Different conclusions on the uniformity of commission rates are found in Sirmans and Turnbull (1997).

${ }^{8}$ Note that Figure 2 reports the distribution of commission rates actually paid by consumers. In a small number of cases, the commission paid differed from the commission originally quoted, as home sellers were given a rebate or were made a gift by the broker. For those cases, the commission reported in the figure is adjusted to reflect the implicit commission rate. Source: FTC (1983), pg. 45.

${ }^{9}$ Source: FTC (1983), Table III-3. The settlement documents are known as standardized HUD-1 forms.

${ }^{10}$ Source: FTC (1983), Table III-7.

${ }^{11}$ For example, it could be the case that as result of the FTC's investigation and numerous consent decrees signed between the US Department of Justice and realtors' organizations, there is now more price competition in real-estate brokerage services.
} 
the house was sold at. ${ }^{12}$ Although the commission rate we obtain from the CEX is noisy, both because of imperfect recall and also because the CEX does not provide a perfect measure of commission fees from home sales, the median commission rate in our sample is 6.1 percent. More importantly, Figure 4 suggests that there is no correlation between these two variables. ${ }^{13}$

What is quite remarkable is that if in fact commission rates are fixed, the commission from selling a house increases one-to-one with the price of the house. For example, the commission paid for the sale of a half-million dollar house is $\$ 30,000$, while the commission from selling a hundred dollar condo is only $\$ 6,000$. Now, one could argue that the brokers who deal with a half-million dollar house are providing a completely difference service than ones dealing with hundred thousand dollar condos. However, it does not seem likely that the difference in services are large enough to account for a 24 thousand dollar difference in the commission fee. But even if this is the case when looking at houses with different prices within a given market, it does not seem very plausible that there are large differences in the average quality of services provided by brokers across cities, despite sizable cross-city variation in the average price of housing. After all, differences in housing costs across cities are largely driven by differences in the price of land, and not by differences in housing quality. ${ }^{14}$

The apparent uniformity of commission rates presents an enormous puzzle, especially if one believes that the cost and effort necessary to sell a house does not increase one-to-one with the price of housing. Why do commission rates appear to be so insensitive to economic forces? We do not have an answer to this puzzle. One possibility is that it reflects collusion by real-estate

\footnotetext{
${ }^{12}$ Roughly two-thirds of the families who sold a house reported paying a commission.

${ }^{13}$ House sales includes "own home" (UCC 820101) and "vacation home" (UCC 820102). We measure commission fees as "total selling expenses" (UCC 820301 and 820302), but this clearly includes other expenses other than commission fees. We estimate commission rate by dividing commission fees by the price of housing. Any measurement error will introduce attenuation bias, leading us to understate the true relationship between price and commission rates. To reduce measurement error, we drop observations with implausibly large or small estimated commission rates (less than 1 percent or more than 10 percent.) We end up with 406 households who report selling their houses and have non-missing price and commission rate. Each point in Figure 4 is the average commission rate within intervals $\$ 10,000$ wide. The superimposed fit is from an household level regression of commission rates on housing prices, which yields a slope coefficient on the log housing price of -0.005 (0.017).

${ }^{14}$ In Section 4 we present evidence that although there are some small differences in the average quality of brokers' services across cities, these differences can explain no more than a fifth of the difference in average commission fees.
} 
brokers, perhaps enforced by the fact that every realtor has to work through the local MLS, which makes price cutting easily detected. ${ }^{15}$ In addition, real-estate is unique in that a broker needs the cooperation of another agent to complete a transaction, which makes punishment for deviating particularly effective. ${ }^{16} \quad{ }^{17}$ A second possibility is that the lack of variation in the commission rate (and the large variation in the price of brokerage services) may simply reflect differences in the elasticities of demand for these services. It is not implausible that the owner of a half-million dollar house is willing to pay a higher commission than the owner of a hundred thousand dollar house. The higher commission paid by the owner of the expensive house may therefore reflect her more inelastic demand for a realtor's service. Free-entry therefore results in more entry and higher prices in markets where the demand is more inelastic. ${ }^{18}$

However, none of these explanations are satisfactory. First, if the fixed commission rate is due to collusion by realtors, it's not clear why realtors collude in this manner instead of colluding to prevent new real-estate agents from earning any profits. Alternatively, if the fixed commission rate simply reflects differences in the elasticity of demand for real-estate services,

\footnotetext{
${ }^{15}$ Historically, realtor organizations published "recommended" commission rates, which were set at 6 or 7 percent. These recommendations were enforced, in part, by the realtors' control over the local MLS, which typically refused to accept listings from brokers who had accepted a commission rate lower than that recommended in the schedule. However, this practice ended in the 1970s due to antitrust action by the Justice Department and numerous consent decrees signed between the Justice Department and realtor organizations. See FTC (1983) for details.

${ }^{16}$ There is evidence that discount brokers are frequently punished by others brokers. For example, the FTC (1983) reports that in a survey of discount brokers, more a third of these brokers experience refusals by newspapers to run their advertisements due to pressure by traditional brokers to boycott publications which run advertisements from discount brokers. In addition, 93 percent of discount brokers reported disparagement of their business to prospective clients by non-discount brokers. Disparagement took the form of statement that the brokers were operating illegally, that they were unethical or unprofessional, or simply that the seller will not succeed in selling their homes through the discount brokers because no other brokers will deal with them. In addition, as any home-buyer will know, many real-estate agents are reluctant to inform the home-buyer of homes that are being directly sold by the owners (known as FSBOs). Since most FSBOs offer to pay the standard 3 percent commission to the buyer's agent, one explanation for this phenomena is that the buyer's agent fears possible retaliation by other agents.

${ }^{17} \mathrm{~A}$ related explanation is that the fixed commission rate is a social norm among real-estate brokers, and that there is a cost associated with deviating from this norm. There is a growing literature that examines how social norms might be important in explaining outcomes such as education, discrimination, childbearing decisions, and crime. Most similar to the convention of fixed commissions is the prevalence of 50-50 splits in share cropping contracts (Burke and Young, 2001). However, we still don't have a good understanding of why certain norms emerge, and not others, and how these norms are sustained.

${ }^{18}$ See Mankiw and Whinston (1986).
} 
the differences in the demand elasticity would have to be enormous to generate an equilibrium in which commissions increase one-to-one with the price of housing. Nonetheless, while a fruitful question for future research is how the competitive market mechanism can yield large variations in price that are seemingly unrelated to the cost of providing the service, our objective in this paper is not to explain the reasons behind this phenomena, but to examine the consequences of the lack of variation in commission rates. ${ }^{19}$

Finally, we want to reiterate that other than the data in the CEX, we do not have evidence on whether commission rates are still fixed at 6 percent today. There is some anecdotal evidence that in the recent years, the emergence of new technologies, particularly the internet, may be loosening the control of realtor organizations over information on the inventory of houses for sale. As previously stated, the empirical work in this paper focuses on 1980 and 1990, when the internet was not available. ${ }^{20}$ Nonetheless, as will be clear later in the paper, to the extent that our assumption of a fixed commission rate is wrong, and commission rates are in fact lower in high housing cost cities in 1980 and 1990, we will observe little correlation between housing prices and our indirect measures of socially wasteful entry by real-estate agents.

\footnotetext{
${ }^{19} \mathrm{An}$ additional puzzle about real-estate brokerage contracts is not only why commission rates are fixed for houses with vastly different prices, but also why they are stated as a fixed percentage of the total selling price rather than a non-linear schedule of the selling price. For example, suppose the price that a realtor can get for a house is given by $\mathrm{P}=\mathrm{P}_{1}+\theta e$, where $\mathrm{e}$ is the effort that the realtor has to put into selling the house. To elicit the maximum effort by the realtor, the commission should be stated as a function of $\mathrm{P}_{-} \mathrm{P}_{1}$, rather than simply as a function of $\mathrm{P}$. One explanation is that the principals in this principal-agent relationship are weak, perhaps because a typical home-seller only sells a house a few times in her lifetime.

${ }^{20}$ A recent Wall Street Journal article ("Home Rules: Real-estate listings on the Web are loosening the grip Realtors have long had on the Market", 10/29/2001) reports that a new web-based real-estate company, eReality.com, "typically charges the seller no more than 4.5 percent in commissions, which is considerably less than the usual 6 percent charged by traditional Realtors." The company gains access to Multiple Listing Services (MLS) by hiring real estate brokers who join local Realtor associations and thus qualify for access to the MLS. The company then gives its customer passwords to search through large sections of the MLS on their own. The strategy faced a legal challenge in 1999 when a Board of Realtors filed a lawsuit alleging eReality.com had violated the rules of the local MLS.
} 


\section{Market Entry and Social Waste}

\subsection{Anecdotal Evidence}

In thinking about what we mean by socially wasteful behavior by real-estate agents, it's useful to think about what real-estate agents do as having two components. First, real-estate agents have to find a client - either somebody who wants to sell her house, or somebody who wants to buy a home. This is called "prospecting" by real estate agents, and includes activities such as door-to-door canvassing, phoning, mailings, and calling on houses for sale by the owner (known as FSBOs). It also includes activities such as establishing a "farm", which can be a small group of people (such as members of a bridge club) or a small neighborhood where the agent establishes a presence by, for example, handing out free pumpkins during Halloween. ${ }^{21}$ Second, after the agent has obtained a client, she has to find a buyer for the property (if the client is a seller) or an appropriate house for the client (if the client is a buyer). While the second activity provides

${ }^{21}$ This dialogue describes how a new real-estate agent learned about the importance of "farming":

"Kennedy, I know it's tough not getting in on the great floor time here," my manager told me a few weeks after I started real estate, "but you can turn it to your advantage." Nell Shukes was trying to cheer me up. With noting to show for many hard hours except a couple of unpromising FSBO situations, I needed cheer.

"Tell me how, Nell."

"Do what that kid out in Simi Valley is doing."

"What kid?"

"Tommy Hopkins."

That was the first time I'd ever heard the name. "So what's he doing?"

"Breaking records," Nell said. "I've been trying to break his record all year. I came close, but_-" Nell leafed through her message and then looked at me. "For Halloween, he rents a truck and loads it up with pumpkin. For Christmas, he throws parties for all the neighborhood kids."

"But how can that pay off? All that expense-"

"There are four or five hundred houses in his neighborhood, Danny. It's active-about 20 percent turnover-and he's getting it all."

"Then he's averaging two listings a week!"

"Right, and he sells most of them himself."

"Four transactions a week!"

She nodded. "Plus the referral business he's doing outside his farm. It does add up."

"His farm?" If I'd heard the term before it hadn't sunk it. Pumpkins, Christmas parties, farms.

This is the real estate business? My mind was reeling.

Source: Kennedy and Jamison (1999) 
a valuable service to home-sellers and home-buyers, the resources spent in the first activity are of marginal social value.

One way to see the importance of prospecting is to look at the contents of any "self-help" book for real-estate agents. For example, the book "How Real Estate Agents Earn Big!" states that "prospecting is the gasoline that fuels the real estate engine. You can't get a career started without prospecting. You can't afford to abandon the habit of prospecting for new business even after your career is zooming right along." 22 One can also count the pages in such self-help books devoted to "prospecting" relative to providing services to buyers and sellers. Consider, for example, the contents of the book, "How to Master the Art of Listing \& Selling Real Estate." ${ }^{23}$ Of the 396 pages in the book, more than half of the book is devoted to chapters with titles such as "How to Acquire Listing Power," "Winning the Good Fight Against For-Sale-by Owners," and "Real Estate's Royal Road to Riches is Called Prospecting." To take another example from another "self-help" book, "How to List and Sell Real-Estate", more than half of the book focuses on topics such as "How to Flip Those Fizzbos Right Into Your Fold," "Sow That Farm and Reap-and Reap-and Reap," and "Danny Kennedy's Full-Year Farming Almanac."24

We do not want to claim that "prospecting" and "farming" are entirely socially wasteful. Our claim is simply that society's gain from free pumpkins during Halloween and from free note-pads with the realtor's picture is far less than what they cost to the realtor, both in terms of the direct cost of these freebies, but particularly in terms of the opportunity cost of the time the realtor puts into such activities. More importantly, our claim is that as long as the commission rate is fixed, the amount of time that realtors devote to prospecting and farming relative to actually selling a house or finding an appropriate house for a buyer increases as the market becomes more competitive - that is, as more realtors are chasing after the same number of customers. In other words, the cost of finding a customer increases with the number of realtors in the market,

\footnotetext{
${ }^{22}$ Tayler (1997)

${ }^{23}$ Hopkins (1991)

${ }^{24}$ Kennedy and Jamison (1999)
} 
without necessarily generating additional benefits to the customer. ${ }^{25}$

\subsection{Theoretical Framework}

In this section, we develop a simple model to illustrate the factors that might determine the extent to which higher commissions in cities with expensive housing are dissipated by market entry. In every city, we will assume that there is a continuum of identical agents distributed uniformly from 0 to $1 .^{26}$ If an individual decides to be a real-estate agent, her earnings depend on the total amount of commissions available in the city $\left(\mathrm{R}_{j}\right)$ and the number of people seeking these commissions $\left(\mathrm{b}_{j}\right) \cdot{ }^{27}$ In the case of the real-estate industry, $R_{j}=c \cdot S_{j} \cdot P_{j}$, where c is the commission rate, $S_{j}$ is the number of housing sales, and $\mathrm{P}_{j}$ is the price of housing in city $\mathrm{j} .{ }^{28}$ The key institutional fact is that the commission rate is fixed at c. On the other hand, if an agent decides not to work as resl-estate agent, her wage is simply given by $\mathrm{w}_{j}$, which represents the reservation wage of every worker in city $\mathrm{j}$.

Entry and Social Waste: Base Case We begin with the simplest version of the model in which the number of sales in a city is exogenous, and labor is the only input in the real-estate business. Since all agents are identical, we assume that each real-estate agent has an equal probability of getting a sale. The expected earnings of a real-estate agent is thus the ratio of

\footnotetext{
${ }^{25}$ Our argument that entry generates socially waste by increasing the marginal cost of obtaining a customer is different from the standard explanation of free entry and social waste which relies on fixed costs being important (see, for example, Mankiw and Whinston (1986)). However, it is possible that the amount of time a realtor has to spend prospecting is actually higher in higher housing cost cities, regardless of the number of realtors in the market. As we'll document later in the paper, we observe more realtors (per capita) in higher housing cost cities. Therefore, we obviously do not know how much time a realtor has to spend on prospecting and farming in high housing cost city in the absence of entry.

${ }^{26}$ We will allow for heterogeneity between agents later.

${ }^{27}$ Because the total number of agents is $1, b_{j}$ is also the number of real-estate agents relative to the total number of people in the city.

${ }^{28}$ We assume that houses are homogeneous within a city, although in the empirical part of the paper we allow for differences in size, age, and other characteristics of a house. In the version of the model with heterogeneous agents, we allow for agents with different abilities to capture different shares of the real estate market, but an equivalent story would be that each agent sells the same number of houses, but agents with higher abilities sell the more expensive houses.
} 
the total amount of commissions available in the city to the number of people seeking these commissions, or $\frac{R_{j}}{b_{j}}$. The equilibrium number of people working as real-estate agents in city $\mathrm{j}$ is determined by the condition that the return from being a real-estate agent has to be equal to her reservation wage, or $w_{j}=\frac{R_{j}}{b_{j}}$. From this simple condition, we can derive the equilibrium number of real-estate agents in city $\mathrm{j}$ :

$$
b_{j}=c \cdot S_{j} \cdot \frac{P_{j}}{w_{j}}
$$

The number of real-estate agents in city $\mathrm{j}$ is thus directly proportional to the price of housing adjusted for the reservation wage in the city. ${ }^{29}$ This is the first testable implication of the model.

A problem with this test is that the variation in $\mathrm{b}_{j}$ could come from variation in $\mathrm{S}_{j}$, as well as from variation in $\mathrm{P}_{j}$. To address this problem, a second testable implication of the model is the relationship between the productivity of real estate agents in a city and the size of the commissions available to real-estate agents - the price of housing. Taking our equation for the equilibrium number of rent-seekers, we can define the productivity of real-estate agents in city $\mathrm{j}$ as the number of houses sold per real-estate agents:

$$
\text { Productivity }_{j} \equiv \frac{S_{j}}{b_{j}}=\frac{1}{c} \cdot \frac{1}{\left(P_{j} / w_{j}\right)}
$$

If the commission rate is fixed and if the wage of every real estate agent is equal to her opportunity cost, the productivity of real-estate agents will be inversely proportional to the price of housing. This version of the model generates the most social waste. The elasticity of $b_{j}$ with respect to $\frac{P_{j}}{w_{j}}$ is 1 , and the elasticity of $\frac{S_{j}}{w_{j}}$ with respect to $\frac{P^{j}}{w^{j}}$ is -1 .

Entry and Social Waste with Increasing Costs So far, we have assumed that other than the additional time a realtor has to spend searching for a client, the cost of working as a realestate agent does not vary across cities. However, it is plausible that brokers have to incur more

\footnotetext{
${ }^{29} \mathrm{By}$ adjusting the price of housing for the reservation wage in the city, we allow the opportunity cost of working outside the real-estate brokerage sector to vary by city. For example, an economic boom that drives up the price of housing in a city will also increase the wage from working in the other sector of the economy.
} 
monetary expenses to sell expensive homes. For example, a broker who deals with half-million dollar homes may need a more expensive office to see customers than a broker who deals with condos worth a hundred thousand dollars. Local services and labor inputs also tend to be more expensive in cities with higher housing prices. In addition, prospecting may involve not only extra working hours, but also monetary expenses (such as the cost of buying freebies.)

The implication of allowing for higher costs in high housing cost cities depends on whether the higher costs are due to "normal" business expenses or whether they reflect expenses that are driven by the entry of new agents. To the extent office rents and other local inputs are more expensive in high housing cost cities, some of the higher commissions in such cities are necessary to cover these additional expenses. If this is the case, the elasticity of productivity to the price of housing will be less than one. ${ }^{30}$

It is also possible that some of the higher cost in high housing cost cities may actually reflect socially wasteful expenses, rather than "normal" business costs. For example, prospecting activities could involve paid advertising in the local press, distribution of flyers and free pumpkins, and mass mailings. Since we measure productivity by sales per hours worked, we only capture social waste that takes the form of time spent by brokers doing things of marginal social value. If part of the social waste is due to higher monetary costs, this would not be captured by our measure of social waste. Therefore, the elasticity of measured productivity with respect to price shocks would also be less than 1 if part of the higher commission is dissipated away by higher monetary costs of prospecting.

\footnotetext{
${ }^{30}$ To see this, suppose $\operatorname{cost}\left(P_{j}\right)=k \cdot P_{j}$ is the cost of working as a real-estate agent in a city. The equilibrium condition becomes $w_{j}=\frac{c \cdot S_{j} \cdot P_{j}}{b_{j}}-k \cdot P_{j}$, which implies that the number of real-estate agents is given by

$$
b_{j}=\frac{c \cdot S_{j} \cdot \frac{P_{j}}{w_{j}}}{1+k \cdot \frac{P_{j}}{w_{j}}}
$$

It is straightforward to see that the elasticity of the number of real-estate agents with respect to the adjusted price of housing is now less than 1 , and the elasticity of productivity with respect to the price of housing is also less than 1 (in absolute value)
} 
Entry and Social Waste in Boom Markets We next relax the assumption that the number of housing sales is invariant to the price of housing. For example, it is reasonable to expect that an economic boom that increases the price of housing will also increase the number of people looking to sell and buy houses. This may make it easier for a real-estate agent to match buyers and sellers. For example, selling houses was very easy for realtors in Silicon Valley during the high-tech boom years in the late 1990s. Houses were sold hours, sometimes only minutes, after being listed. ${ }^{31}$ This effect is likely to lead us to underestimate the amount of social waste due to entry. As previously stated, our indirect test for social waste is based on the correlation of housing price shocks and the productivity of brokers. To the extent that it is easier for brokers to sell houses in good times, the productivity of brokers should increase, everything else constant. Therefore, any negative impact of price shocks on productivity that we may find should be considered a lower bound of the true amount of social waste.

Entry and Social Waste with "Star" Agents Finally, we allow agents to differ by ability. This implies that there may significant differences in earnings between agents, and the earnings of some agents may exceed the opportunity cost of their time. For example, in every real-estate market, there are a small number of "star" agents that appear to do extremely well. In this model, an increase in the total amount of commissions available (as represented by an increase in $\mathrm{P}_{j}$ ) will still result in the dissipation of the higher commissions by an increase in the number of people seeking these commissions. However, because part of the higher price of housing translates into higher earnings for some real-estate agents, there may be less social waste than in world in which the wage of every rent-seeker is equal to her reservation wage. See Appendix 1 for details of this model. ${ }^{32}$

\footnotetext{
${ }^{31}$ There is abundant empirical evidence of a strong positive correlation between housing prices and sales volume and a negative correlation between housing prices and the amount of time a house remains on the market. See Stein (1995) and Genesove and Mayer (2001).

${ }^{32}$ When products are differentiated, additional entry can be welfare improving by increasing the product space. If agents are differentiated in the types of services they provide, high price markets might yield welfare benefits to home buyers and sellers.
} 


\section{Empirical Evidence}

As a reminder to the reader, if commission rates do not vary and barriers to entry are low, our hypothesis is there will be more market entry and more social waste in cities with higher housing prices (or where housing prices have increased). In this section, we turn to cross-city evidence to test this conjecture. In our base case model, higher commissions in high housing cost cities are fully dissipated by market entry: the elasticity of number of brokers with respect to price shocks is 1 and the elasticity of productivity with respect to price shocks is -1 .

However, in reviewing the empirical evidence, it's important to bear in mind that there are a number of reasons why the elasticity may not be exactly equal to 1 . First, our story is based on the assumption that commission rates are fixed. However, if commission rates are actually lower in high housing cost cities, then the elasticity of the number of brokers (and productivity) with respect to the price of housing will be less than one. In the limit, if commission rates adjusted fully to price shocks, we should observe no correlation between changes in productivity and price shocks. Even if commission rates are invariant, there are two reasons why higher commission fees in more expensive cities may not be completely dissipated by entry. First, "normal" business costs may be higher in a city with high housing prices. Second, it may be the case that "star" agents in high housing cost cities have higher earnings than similar "stars" in low housing cost cities, so part of the higher commissions in high cost cities are captured by these "star" agents.

On the other hand, there are two reasons why our measures potentially understate the extent to which higher commissions generate socially wasteful market entry. First, socially wasteful activities may take the form of additional expenditures on things like advertising, mailing, pumpkins, and note-pads. Since we measure productivity as sales per agent or sales per hour worked, we do not capture any social waste that takes the form of additional monetary expenditures in expensive cities. Second, it's reasonable to expect that the time and effort required to match

buyers and sellers will be lower in "boom" markets. Both factors suggest that the elasticity of our measures of rent-seeking with respect to the price of housing potentially understate the 
extent to which higher commissions are dissipated by socially wasteful entry.

\subsection{Data}

Our main data source is the 5 percent sample of the Census of Population and Housing in 1980 and 1990. We define a "market" as a metropolitan area (MSA). ${ }^{33}$ In total, we have a sample of $282 \mathrm{MSAs}$ for both years. We identify real-estate agents as individuals who reported their occupation as "real-estate sales occupation" in the Census. ${ }^{34}$ To measure the number of houses sold in a city, we use information on the date in which the household moved to the current house along with information on whether the household owns the house in which it lives. ${ }^{35}$ The Census also asks homeowners about the value of their house, which we take as our measure of the price of housing. In the paper we present results based on the average price of housing in a city, although the results are virtually identical if we use the average price of houses sold in the last year. ${ }^{36}$

Table 1 presents the summary statistics of the sample. In an average city, we have a sample of 7,457 households and 137 realtors in 1990, and 5,288 families and 112 realtors in 1980 . We define productivity in two ways: as the total number of sales in the city divided by the total number of realtors and as the total number of sales in the city divided by the total number of hours worked by realtors. In Table 1, we report average productivity according to the second definition. The average real price of houses is $\$ 94,142$ in 1990 and $\$ 85,826$ in $1980 .^{37}$

Table 2 (top panel) reports the cities with the highest and the lowest cost of housing, as well as

\footnotetext{
${ }^{33}$ Since the definition of metropolitan areas changes from 1980 to 1990, we redefine 1990 MSAs to be consistent with the 1980 definition. See Moretti (2000) for details on the match.

${ }^{34}$ The occupation code for "real-estate sales occupation" in the Census is 254 in the "Sales Representatives, Finance and Business Services" category. This classification includes both real-estate agents and brokers, but we disregard this distinction for most of the analysis. Results discussed below indicate that this distinction is empirically not important for our analysis.

${ }^{35}$ Specifically, we define an observation as a sale in 1990 if the respondent reports that she owns the house and moved into the house in 1990 or 1989 . The definition for 1980 is analogous. Note that since the Census takes place in April, we are identifying sales that take place during the previous 15-16 months. In Table 1 we report adjusted means that reflect sales over a 12 month period. Since the value of the house is in discrete categories, we use the mid points of each category to transform it into a continuous variable.

${ }^{36}$ In 1990, the correlation between the average price of the stock of houses in a city and the average price of houses sold in the last year was 0.99 , so it makes little difference which measure is used.

${ }^{37}$ In 1990 dollars.
} 
the average productivity of brokers in these cities (defined as sales per hours worked) in 1990. As can be seen, the price of housing in the ten most expensive cities is almost six times higher than the price of housing in the ten cities with the lowest cost of housing. In turn, the productivity of brokers in the low cost cities is about four and a half times higher than the productivity of real-estate agents in the high cost cities. The bottom panel reports cities with the largest and the smallest percent change in cost of housing between 1980 and 1990, as well as the percent change in productivity of brokers in these cities. Cities that experienced large increases in price of houses also experienced large decreases in the productivity of realtors, while the productivity of real-estate brokers generally decreased less in cities where the price of housing fell, and in some cases productivity actually increased. Note that the cities with the largest (smallest) increase in the price of housing between 1980 and 1990 are not the same as those with the highest (lowest) price of housing in 1990.

As one way to assess the reliability of the Census' measure of the number of real-estate agents, we use data from state licensing boards on the number of people with active real-estate licenses (see Table A1). This data is not available at the city level, but only at the state level. When we aggregate our Census data to the state level, the correlation between our estimate of the number of brokers by state and the number of active licensed brokers from the state licensing boards is 0.92. This suggests that the number of brokers estimated using self-reported occupation in the Census reflect fairly accurately the actual number of licensed brokers.

Finally, in interpreting the results we present below, it is important to bear in mind that although the Census provides an accurate measure of housing sales in a city, we can not assume that all these transactions are conducted through brokers. Clearly, some home-sellers choose to avoid paying the brokerage fees by selling their homes by themselves. The resulting bias depends on the extent to which the fraction of houses directly sold by the owner is correlated with the price of house. ${ }^{38}$

\footnotetext{
${ }^{38}$ Our evidence from the CEX suggests that the fraction of houses directly sold by the owner falls with the price of the house. An OLS regression of a dummy equal to 1 if the house is sold by the owner on log price and
} 


\subsection{Housing Prices, Market Entry, and Social Waste across Cities}

We now turn to the three testable implications of our story that a fixed commission rate generates socially wasteful market entry, using both the cross-sectional variation and 1980-1990 changes in housing prices across cities. First, the fraction of realtors in a city (relative to the population) should be increasing in the price of housing (equation 1). Second, the productivity of an average realtor should be lower in a city with higher housing prices (equation 2). Third, in equilibrium, brokers should be indifferent across cities: their real wage should be uncorrelated with price of housing.

Relative Number of Real-Estate Agents We begin with two scatter plots. Figure 5 presents the cross-sectional relationship between the fraction of real estate agents in a city and the unadjusted average price of housing in the city. Figure 6 plots the changes in the fraction of real estate agents from 1980 to 1990 against changes in price of housing. There are 282 cities in our sample. As can be seen, two facts are clear from these figures. First, there are more real estate agents (relative to the total labor force in the city) in cities with higher housing prices. Second, this relationship also holds true when considering changes over time. ${ }^{39}$

We then turn to estimates of equation 1, which relates the number of brokers to normalized housing prices. Specifically, we regress the $(\log )$ ratio of number of brokers in the city to the total number of workers in the city on the (log) average price of houses in the city normalized by the city-specific reservation wage of brokers. ${ }^{40}$ The estimates of the city-specific reservation wage of real estate agents are obtained as a weighted average of the wages of workers in all other occupations in the same city. We assign weights to individuals in the sample who are not brokers based on how similar their observable characteristics are to the observable characteristics

year dummies yields a coefficient on log price equal to -.13 (.015).

${ }^{39}$ The OLS coefficients on housing prices are, respectively, $0.462(0.045) ; 0.845(0.086) ; 0.702(0.060)$. All models are weighted by city population.

${ }^{40}$ The regression differs from Figures 5 and 6 because the independent variable is now normalized housing prices, not housing prices. The regression therefore accounts for the fact that the reservation wage of brokers differ across cities. 
of brokers. ${ }^{41}$ The cross sectional coefficients are both positive and significant. For the 1990 crosssection, the coefficient (standard error) is 0.623 (0.058). The corresponding coefficient for 1980 , is slightly larger: $1.142(0.097) .{ }^{42}$

To abstract from some of the factors that can potentially introduce spurious correlation between the share of brokers and the price of housing in the cross-section of cities, we also look at how changes over time in the normalized price of housing affect changes in the number of real-estate agents. The estimated coefficient is $0.917(0.078)$, indicating that a 1 percent increase in the average cost of housing in a city results in a 0.9 percent increase in the number of real estate agents. To help interpret the magnitude of the estimated effect, consider cities like Seattle, Raleigh-Durham and San Diego that are around the 75th percentile in the distribution of changes in housing prices from 1980 to 1990. In these three cities, the value of houses sold in 1990 was 16-19 percent higher (in real dollars) than in 1980. The point estimate of the coefficient implies that in these cities, the number of real-estate agents increased by 15-18 percent over ten years (holding population constant).

Finally, to allow for the fact that many real-estate agents work part time, we re-estimate all the models using the log ratio of hours worked by real estate agents over the total hours worked by all workers in the city as an alternative measure of labor supply. The resulting estimates of the elasticity of the labor supply of brokers to the price of housing are virtually identical to those using the number of brokers in a city as the dependent variable. ${ }^{43}$

Productivity of Real-Estate Agents We have shown that the number of hours worked by real-estate agents in a city (relative to the total hours worked in a city) increases when the price of

\footnotetext{
${ }^{41}$ In particular, we obtain the weights from a probit model where the dependent variable is a dummy equal one for brokers, and the independent variables include gender, race, schooling, a quadratic in experience, and the interaction of gender with race, schooling, and a quadratic in experience. We have experimented with different definitions of the reservation wage, and have found that our results are not sensitive to these alternatives. For example, when we use the average wage in the city or average white collar wage in the city, the results are virtually unchanged.

${ }^{42}$ All the models are weighted by city population. The $R^{2}$ are 0.28 and 0.32 , respectively.

${ }^{43}$ The estimates are $0.667(0.060), 1.228(0.099)$, and 0.838 (0.081) for the 1990 cross-section, the 1980 crosssection, and for 1980-1990 changes, respectively.
} 
housing increases. This is consistent with a story in which positive price shocks results in market entry by brokers (equation 1). However, an alternative explanation is that cities where housing prices have increased also experience a higher demand for brokerage services. To discriminate between these two explanations, we turn to our main piece of empirical evidence: the relationship between productivity and housing prices. If the fixed commission rate results in socially wasteful entry, then we should see that an increase in housing prices lowers the productivity of real-estate brokers. On the other hand, if the positive correlation between hours worked and housing prices simply reflect a shift in demand, there should be no effect on productivity.

The ideal dataset to test our model would be a longitudinal dataset where the same house is sold multiple times, both in expansion years and in recession years. If such a dataset were available, we could regress the change between expansions and recessions on the amount of time that it takes for brokers to sell the same house on the change in the price of the house. By looking at the same house, we would be able to completely abstract from changes in the quality of housing that might affect the amount of time required to brokers to sell the house. We don't have such longitudinal data, but below we provide evidence indicating that our results are robust to observed and unobserved housing characteristics.

As before, we start with a scatter plot of the correlation between unadjusted price of housing and productivity of realtors. We define productivity as the ratio of the total number of sales in a city over the total number of hours worked by brokers in the city, although the results are virtually identical if we define productivity as sales per broker. Figure 7 shows that both in 1980 and 1990, the cross sectional relationship between productivity and housing prices is consistent with our prediction: the productivity of brokers is lower in cities with high housing prices than in cities with low housing prices. The same is true when looking at changes over time from 1980 to 1990 (Figure 1). ${ }^{44}$

We then turn to estimates of equation 2. We regress the (log) average productivity of brokers in the city on the (log) average cost of housing normalized by the city-specific reservation wage

\footnotetext{
${ }^{44}$ The OLS coefficients on housing prices are, respectively, -0.725 (0.029); $-0.953(0.040) ;-0.512(0.052)$.
} 
of brokers. ${ }^{45}$ A regression based on the 1990 cross section yields a coefficient of -0.929 (0.059), suggesting that a one percent increase in cost of housing in a city is associated with 0.92 percent decrease in the number of houses sold per hours worked. A similar estimate for the 1980 cross section yields a larger coefficient (in absolute value) than that from the 1990 cross-section: 1.098 (0.049). ${ }^{46}$ In other words, the estimated cross-sectional elasticities suggest that higher commissions in higher cost cities are almost completely dissipated by entry.

The estimated elasticity of productivity to housing prices using 1980-1990 changes is -0.646 (0.069) and highly significant. This estimate, which abstracts from any fixed city-specific factors that might affect the work necessary to match buyers and sellers, suggests that part of the crosssectional correlation and housing prices is due to permanent unobserved characteristics of cities such as density and unobserved quality of the stock of housing. Nonetheless, once we control for such city-specific factors, it is still the case that roughly two-thirds of the higher commissions due to high housing prices are dissipated through entry. ${ }^{47}$

A legitimate concern is that markets that experience increases in housing prices will not only have more brokers, but also a different distribution of the brokers' abilities. Changes in the ability distribution of brokers could lead us to overestimate or underestimate the coefficient on housing prices, depending on whether high housing prices are associated with high or low average ability of brokers. For example, one might think that brokers in expensive cities like New York or San Francisco have higher ability than brokers in less expensive cities. On the other hand, if established, high ability agents can't easily migrate across cities, it is possible that the new brokers who enter the market following an increase in housing prices are of lower quality. Our estimates account for differences in brokers observable characteristics across cities, because our measure of housing price is adjusted for the brokers' reservation wage, which is imputed based on the brokers' observable characteristics. But is still possible that unobservable heterogeneity

\footnotetext{
${ }^{45}$ Once again, the difference between the regression and the Figures is that in the regression, the price of housing is normalized by reservation wage.

${ }^{46}$ The $R^{2}$ for 1990 and 1980 are 0.65 and 0.63 , respectively.

${ }^{47}$ In section 4.3 below, we show that this estimate does not change when we control for observable and unobservable housing characteristics.
} 
in brokers quality biases our estimates.

While we can not directly assess the magnitude of the resulting bias, we examine how observable characteristics of brokers vary depending on housing prices. If observable characteristics of brokers are correlated with housing prices, it is likely that unobservable characteristics are correlated with housing prices as well. ${ }^{48}$ The first row of Table 3 indicates that brokers in cities with higher housing prices are more likely to have a college or community college education in 1990 and 1980 (columns 2 and 3). When we introduce city fixed effects (column 4), the coefficient drops to 0 . A similar pattern emerges when we look at years of schooling (row 2), fraction of realtors who work part time (row 3), and fraction of realtors who are females (row 4). ${ }^{49}$ For completeness, in the last two rows, we report estimates for race and age. Overall, the evidence suggests that when looking at a cross-section of cities, brokers appear to be slightly more skilled in markets with higher housing prices. However, when we absorb city fixed effects, we find little evidence of a correlation between housing prices and broker observable quality.

Housing Prices and Brokers' Earnings We now turn to the third implication of our story of socially wasteful market entry: in equilibrium, brokers should be indifferent among cities. Specifically, we test whether the average real earnings for brokers are the same in high housing cost cities as in cities with lower housing costs.

To begin, we show the relationship between the expected revenue of real-estate agents, computed as 6 percent of the total value of homes sold in a city, and the actual total value of brokers' earnings in the city, as reported by brokers in the Census. Under the following assumptions: (1) the commission rate for all transactions is 6 percent; (2) brokers' earnings comes exclusively from sales of residential homes; and (3) brokers report their revenues from commissions as their earnings, the sum of earnings reported by all brokers in a city should be exactly equal to 6 percent of the sum of the value of all home sales in the city. Figure 8 plots the log of actual brokers

\footnotetext{
${ }^{48}$ See Altonji, Elder, and Taber (2002).

${ }^{49}$ Part time is defined as working less than 30 hours a week.
} 
earnings against the log of expected brokers' earnings for 282 cities. If the three assumptions above are true, then we should observe a slope equal to 1 . The coefficient in a regression of log expected brokers' earnings on log actual earnings is $1.08(0.01)$.

Having shown evidence suggesting that reported brokers' earnings in the Census appears to closely reflect revenues from housing sales, we now assess whether brokers in high cost cities have higher earnings (relative to their opportunity cost) than brokers in low-cost cities. As can be seen in first two columns in Table 4, the relative wage of brokers appears to be higher in expensive cities when looking at the cross-section of cities. ${ }^{50}$ The point estimate for the 1990 cross-section indicates that the relative wages of brokers are 0.8 percent higher in a city where housing prices are 10 percent higher. However, when turning to the evidence based on 1980-1990 changes (column 3 in Table 4 and figure 9), there is little evidence that relative wages of brokers increase by more in cities where housing prices have increased by more.

We speculate that the difference between cross sectional estimates and city fixed effects estimates in Table 4 may in part reflect differences in brokers unobservable skills across cities. Specifically, it is possible that brokers of higher ability are found in cities with higher property values, and that average ability gets differenced out in models based on 1980-1990 changes. This hypothesis is consistent with the finding that brokers' observable characteristics are correlated with housing prices in the 1980 and 1990 cross setctions, but not in models based on 1980-1990 changes (see Table 3). In other words, when looking at a cross-section of cities, it is not only the case that the brokers in expensive cities appear to be of higher quality based on their observable characteristics, but that their unobservable quality appears to be higher as well. However, there is no evidence of this relationship when looking at changes over time.

In addition to looking at mean earnings, it is also useful to look at the effect of price increases on the dispersion of earnings. We first look at the correlation between the interquartile range of agents' earnings in a city and the price of housing. ${ }^{51}$ We find that price increases are associated

\footnotetext{
${ }^{50}$ Remember that the reservation wage is defined as a city-specific weighted average of earnings of workers outside real-estate, with higher weights given to workers who have characteristics similar to those of brokers.

${ }^{51}$ Unlike the variance, the interquartile range is robust to outliers.
} 
with statistically significant increases in the interquartile range, both in the cross section and in 1980-1990 changes. $^{52}$ We find similar results when we look at the conditional interquartile range of earnings. ${ }^{53}$

Another potential source of earnings dispersion is the difference between brokers and agents. Until now, we have not distinguished between brokers and real-estate agents, but it is possible that brokers in high housing cost cities may profit from the fixed commission fee. ${ }^{54}$ However, we find that the relative number and the relative earnings of brokers compared to the number and earnings of agents in a city are not correlated with housing prices, which suggests that the distinction between brokers and agents is not important empirically in our analysis. ${ }^{55}$

\footnotetext{
${ }^{52}$ The cross sectional coefficients for 1990 and 1980 are respectively $2.078(0.147)$ and $2.10(0.174)$. The specification in changes yields 1.415 (0.309).

${ }^{53}$ The cross sectional coefficients for 1990 and 1980 are respectively $1.74(0.12)$ and $2.02(0.14)$. The specification in changes yields $1.48(0.23)$. The conditional interquartile range is obtained by conditioning on schooling, gender, race and a quadratic in potential experience

${ }^{54}$ As previously mentioned, every agent has to work for a broker. Most brokers are themselves also sales-agents (or former agents) and are typically the owners of the real-estate company. A recent survey by the National Association of Realtors indicates that in $59 \%$ of cases, agents split commission fees with their broker, in $32 \%$ of cases agents get the full commission (and pay a fixed fee to the broker), and in $4 \%$ of cases receive a fixed salary (Source: Realtors Compensation Study, described in Realtor Magazine, 8/1/2001).

${ }^{55}$ Specifically, we find no relationship, both in a cross-section of MSAs and over time, between the ratio of earnings of brokers over the sum of earnings of agents and brokers and housing prices. In the Census, we use information on the "class of worker" to identify whether an individual involved in the "real-estate sales occupations" is a broker or an agent. Specifically, we classify the individual as a broker if she is "self-employed in own not incorporated business, professional practice, or farm" or "self-employed in own incorporated business, professional practice or farm". We classify her as an agent if she is an "employee of a private for profit company or business or of an individual, for wages, salary, or commissions".

Second, we find no correlation between the ratio of the number of brokers to the sum of the number of brokers and agents and housing prices. This is true both when using the Census data to look across MSAs and when using data from state licensing boards to look across states. The data from state licensing boards is collected by The National Association of Real Estate License Law Officials (NARELLO). This organization reports separately the number of licensed brokers and the number of agents in each state (but not by MSA). The NARELLO data are likely to be more precise than the Census data, but are available only at the state level. When aggregated at the state level, the number of brokers and salespersons estimated with Census data is highly correlated with the numbers provided by NARELLO (the correlation is around .8). In a cross-sectional regression of number of brokers divided by brokers plus salespersons on $(\log )$ housing prices, both datasets yield statistically insignificant coefficients. When looking at the 1980-1990 changes, the Census data yields a marginally significant negative coefficient of $-.0497(.0226)$.
} 


\subsection{Does Heterogeneity of Housing Matter?}

An important limitation with the evidence we've presented so far is that the average quality of housing may differ according to the average price of housing in the city, and that differences in housing quality may affect the quality of real-estate brokerage services. For example, it is possible that selling older and larger houses takes more time than selling newer and smaller houses. If this is the case, some of the correlation uncovered in Figures 1 and 7 could reflect heterogeneity in housing quality. In this section we report estimates designed to probe the robustness of our results to potential heterogeneity in the housing stock.

By looking at changes over time in the same city, we have made a first step to control for characteristics of the housing stock that are correlated with prices and may affect productivity. It is likely that many unobserved characteristics that may affect brokers' productivity in a city are fairly permanent, and can be absorbed in specifications that control for city fixed effects. However, the sample of houses in 1990 does not need to be exactly the same as the sample in 1980, since new homes have been built between 1980 and 1990. In column 2 of Table 5 we report the estimates from a specification that controls for the changes in housing characteristics. Specifically, we include the change in the average age of housing, average number of bedrooms, percentage of one-family houses, percentage of housing that are condominiums, and percentage of houses with kitchen and plumbing. The quantitative impact of controlling for observable characteristics of houses is quite limited. The coefficient in column 1 is -0.71 , slightly more negative than the corresponding coefficient from the model that does not include controls (column 1). 56

However, we are concerned that these controls absorb only some of the potential heterogeneity,

\footnotetext{
${ }^{56}$ Since it is possible that the extra controls are endogenous, we have to be careful in interpreting the results of this regression. The sign of the coefficient estimates on the added controls is consistent with some of the added variables being endogenous. For example, controlling for housing prices, the age of housing has a positive effect on productivity. Since we expect older houses to be more difficult to sell, this estimate makes little sense if age of housing is in fact controlling for changes in the difficulty of selling that are correlated with housing prices. Instead a more reasonable interpretation is that economic booms that increase housing prices also translate into building booms that lower the average age of housing.
} 
and that there may be changes in unobserved characteristics of the housing stock that affect brokers' productivity and that are correlated with housing prices. One way to partially address this problem is to isolate the component of changes in housing prices that are driven by changes in the price of land, rather than by changes in housing quality. The idea is that changes in land prices do not directly affect brokers' productivity, but if our model is correct, they affect it indirectly through their effect on entry by new brokers. While so far we have looked at the total effect of prices on productivity, we now use two instrumental variables to isolate the effect of changes in land prices on productivity.

First, we use a price index of a panel of houses in 119 cities compiled by the Office of Federal Housing Enterprise Oversight (OFHEO). Since the OFHEO index measures the price of the same houses over time, it allows us to isolate the component of price changes that is exclusively due to changes in land prices. ${ }^{57}$ We use the change in OFHEO price index as an instrumental variable for the change in average housing prices. The resulting estimate, shown in column 3 of Table 5 is similar to the corresponding OLS estimate in column 1.

A similar approach is to use the Census to estimate the cost of housing, but restricting the sample only to houses existing both in 1980 and 1990. Specifically, we estimate the change in housing prices restricting the 1990 sample to houses that are 10 years or older, so that only houses that existed in 1980 are included in the calculation. Clearly, this is not a true panel, but it is a representative sample of the population of houses existing in both years. The price changes in this restricted sample are not driven by changes in the quality of new houses, but mainly reflect changes in the price of land. This index is similar in spirit to the OFHEO price index, but has the advantage of being available for all the 282 cities in the sample. In column 4 , we use the change in prices calculated on the sample of houses existing both in 1980 and 1990

\footnotetext{
${ }^{57}$ The OFHEO index has been compiled since January 1975 from repeat mortgage transactions on single-family homes whose mortgages have been purchased or securitized by Fannie Mae or Freddie Mac. Although the OFHEO price index is driven primarily by land prices, depreciation and renovation also will potentially affect the index. There are, however, two limitations with the OFHEO price index. First, the index is limited to sales of existing single-family homes, and does not include sales of new homes, and sales of non-single-family homes. Second, while the index allows us to measure changes in housing prices over time, it can not be used for cross-sectional comparisons.
} 
as an instrument for the change in total price of housing. Again, the IV estimate is very similar to the OLS estimate.

Finally, we present additional estimates to check the robustness of our results. The top row in Table 6 replicates our base case estimates (from Figures 1 and 7). In the second row in Table 6 , we estimate a model where the dependent variable is the number of bedrooms in houses sold in the city for every hour worked by brokers. While we have already controlled for the size of houses by conditioning on the number of bedrooms (in Table 5), this is an alternative way to make sure that our results are not driven by differences in the size of homes across cities. When we measure productivity as the number of bedrooms sold per hour, the coefficients are similar to or slightly larger than the base case estimates.

In row 3, we control for the population in the city, and the fourth row controls for the percentage of renters in the city. We introduce the latter as a control because we are concerned that some brokers work on leases as well as sales, and the amount of time spent on leases may be correlated with housing prices. In the fifth row, we use median price of houses instead of the mean price. ${ }^{58}$ Finally, in row 6 we drop New York city because New York city is one of the few markets, and the only one among the large cities, that has no Multiple Listing System. As can be seen, none of these adjustments have a large impact on the estimated effect of housing prices on the productivity of real-estate agents.

\subsection{Are More Expensive Houses More Difficult to Sell?}

In this section, we turn to an assessment of how much of our results can be explained by increased services to customers in cities where housing prices have increased. In our most robust specification (that based on 1980-1990 changes), we find that between two thirds and three fourths of the higher commission in cities with high housing prices is dissipated through lower productivity of real-estate agents. However, although these results are robust to differences in the character-

\footnotetext{
${ }^{58}$ Since the price of housing is top-coded in the Census, the mean price is sensitive to how the top coded values are treated, while the median price is not.
} 
istics of housing across cities, it could be the case that as land prices rise, it takes more time to sell a house. Alternatively, even if the time that it takes to sell a home for sale does not vary according to price, buyers in cities with high housing prices may visit more houses before making a decision. In either case, the correlation between higher prices and lower productivity shown in Figures 1 and 7 could simply reflect the fact that brokers in expensive cities need to spend more time matching buyers and sellers.

While we can not completely rule out this possibility, we present two pieces of evidence that are inconsistent with this view. First, a direct measure of the amount of time brokers spend selling a house is the duration of vacancies. Ideally, we would like to observe the amount of time that brokers spend trying to sell a house. We do not have this data, but for the sample of houses that are vacant and for sale, the Census provides information on the amount of time the house has been on the market. ${ }^{59}$ Figure 10 shows that the cross-sectional relationship between time on the market and housing prices in 1990 is negative. This negative relationship is confirmed in columns 1 and 2 in Table 7, which presents regressions of the average duration of vacancies in a city on the price of housing in the city in 1980 and 1990, respectively. When we control for city fixed effects in column 3 , the coefficient on housing prices remains negative.

While one could argue that the time on the market is endogenous, as a higher effort from brokers could lead to a quicker sale, the negative relationship uncovered in Table 7 is also consistent with the observation that it is easier to sell houses when the local economy is booming. The extreme example is the real estate market boom in the Silicon Valley in the late 1990s when every property sold within a few days. ${ }^{60}$ In sum, while we do not have conclusive evidence that houses in more expensive cities are easier to sell, what we can say with reasonable certainty is that it does not take more time to sell a house in an expensive city.

\footnotetext{
${ }^{59}$ The variable "time on the market" is categorical in the Census. We make it continuous by taking the midpoints of each category.

${ }^{60}$ See Stein (1995) and Genesove and Mayer (2001). One explanation proposed for the negative relationship between time on the market and housing prices involves loss aversion. Genesove and Mayer (2001) show that during downturns, sellers facing a potential loss have higher reservation prices and therefore face a longer time on the market.
} 
However, while this evidence suggests that brokers do not spend more time selling a house in a high housing cost city, it is still possible that buyers of such houses tend to take more time searching. Therefore, if buyers' agents need to spend more time assisting home-buyers, this could explain some of the correlation between productivity and housing prices. To assess this argument, we turn to two measures of the duration of the search by home-buyers.

Our first proxy of the time buyers spend searching for a house is the average number of houses visited by home-buyers in 20 large cities. ${ }^{61}$ The average home buyer in these cities visited 13.3 houses before making a decision. The top panel of Figure 11 shows the relationship between log average number of houses visited by home-buyers in each city and log average housing prices. The corresponding coefficient from a regression of the logarithm of the number of houses visited on the log of the price (first column in Table 8) is 0.135 (0.099). This estimate suggests that the number of houses visited by home-buyers increases with housing prices, but the effect is small and not statistically different from zero.

We obtain similar results when we use the number of months spent by home-buyers searching for a house as an alternative measure of the amount of time a realtor spends matching buyers and sellers. Specifically, we use household level data from a survey of 3,839 home-buyers collected by the National Association of Realtors from 1984 to $2000 .^{62}$ The bottom panel of Figure 11 suggests that the relationship between search duration and price is weak. The corresponding estimates in columns 2 and 3 of Table 8 confirm that the effect of prices on search duration is small, and the point estimates are similar to the model based on the number of visits. ${ }^{63}$

\footnotetext{
${ }^{61}$ The data is from the 1999 Annual Survey of Recent Home Buyers, a representative survey of approximately 1,800 home buyers in 20 major cities collected annually by the Chicago Title and Trust Company (www.ctt.com). The cities included in the survey are Atlanta, Boston, Chicago, Cleveland, Dallas-Fort Worth, Denver, Detroit, Houston, Los Angeles, Memphis, Miami, Minneapolis-St. Paul, New York City, Orange County (CA), Orlando (FL), Philadelphia, Phoenix, San Francisco, Seattle-Tacoma, and Washington, D.C. Although the number of cities covered by this survey is a fraction of the total number of cities for which we have data in the Census, the 20 markets in the Annual Survey of Recent Home Buyers account for approximately one-third of all home sales in the United States.

${ }^{62}$ Unlike the evidence on the number of houses visited which are city-level averages, this regression relates the actual search duration of a household to the actual price paid for the house.

${ }^{63}$ The second column reports estimates from a model that controls for year effects. Column 3 refers to a model that controls for year effects, as well as age of the house and number of bedrooms.
} 
In sum, these estimates suggest that buyers of more expensive houses seem to search longer, and in the process, they visit more houses. However, the effect is small. The point estimates in Table 8 suggest that if excessive entry did not take place, the commissions of brokers in a city where property prices are ten percent higher should only be 1-1.3 percent higher. Instead, our estimates from Table 5 suggests that commissions are 7 percent higher in such cities. Therefore, the additional amount of time home-buyers spend searching for a house in high housing cost cities can explain no more than 18 percent of the higher commissions in these cities.

\section{$5 \quad$ How Large are the Social Losses from Excessive Entry?}

We now quantify the social losses from excess entry. If we assume that the demand curve for brokerage services is price inelastic and that the earnings of brokers is equal to their opportunity cost, the social losses from excess entry in a city can be approximated by the difference between the total earnings of brokers in a city and total variable costs. ${ }^{64}$ The main difficulty is that we do not observe costs, and we need to rely on assumptions that are necessarily arbitrary. To impute costs, we use the fact that our most robust estimate indicates that wasteful entry lowers the productivity of real-estate agents by 7 percent in a city where housing prices are 10 percent higher. Based on this finding, we infer that marginal costs should increase by 3 percent for each 10 percent increase in housing prices. Therefore, if we can identify a benchmark city where there is no excessive entry, the total variable costs in city $\mathrm{j}$ can be approximated as:

$$
\operatorname{Cost}_{j}=\frac{S_{j} \cdot w_{j}}{\text { Productivity }_{\text {benchmark }}} \cdot\left(1+0.3 \cdot \ln \left(\frac{P_{j}}{P_{\text {benchmark }}}\right)\right)
$$

where Productivity benchmark and $P_{\text {benchmark }}$ refers to the productivity (sales per hours worked) and the average price of housing in a benchmark city. It is easy to see that equation 3 assumes that there is no socially wasteful entry in the benchmark city, since cost equals total earnings of

\footnotetext{
${ }^{64}$ If the demand curve is somewhat price elastic, we will also have the usual loss from pricing above marginal cost. We abstract from this triangle loss in our calculations.
} 
brokers. ${ }^{65}$ For cities with productivity lower than the benchmark city, the first term in equation 3 calculates what brokers earnings would have been, had their productivity been equal to the productivity of brokers in the benchmark city. The second term in equation 3 accounts for the fact that cities with lower productivity have higher price of housing, which results in higher cost of doing business. In particular, based on our estimates, the second term in equation 3 assumes that $30 \%$ of the additional price of housing relative to the benchmark city translates into higher costs. The total social loss from excess entry is the sum over all cities of the difference of total earnings of brokers in a city and the imputed variable cost. ${ }^{66}$

Using this formula, Table 9 presents alternative estimates of the total social losses from excess entry in 1990. Because we don't know which city has an efficient real-estate brokerage industry, we present estimates based on four different cities as possible benchmarks. For reference, column 1 in Table 9 reports total earnings of brokers in 1990, which is $\$ 16.1$ billions. ${ }^{67}$ The second column uses the city at the $90^{\text {th }}$ percentile of the brokers productivity distribution (Athens, GA) as the benchmark. This estimate suggests that the social loss from excess entry in 1990 is roughly 8.2 billion dollars. ${ }^{68}$ We assume that there is no socially inefficient entry in cities where the productivity of realtors is higher than in the relevant benchmark city. ${ }^{69}$ The subsequent columns use cities with lower productivity (higher marginal costs) as benchmark markets. The benchmarks in columns 3 to 5 are the cities at the $75^{t h}, 50^{\text {th }}$, and $25^{\text {th }}$ percentile of the productivity distribution, respectively. Since the benchmark marginal cost increases and the number of cities in which we assume that there is no socially wasteful entry also increases as we move from

\footnotetext{
${ }^{65}$ To the extent that this is not true and there is some socially wasteful entry in the benchmark city, then equation 3 will overstate variable costs and thus understate the social waste from entry in city $\mathrm{j}$.

${ }^{66}$ See Berry and Waldfogel $(1999,2001)$ for an alternative approach to the estimation of social loss from free entry.

${ }^{67}$ As we have shown in Section 4.2, variation in total earnings of brokers closely matches $6 \%$ of total value of houses sold. In our sample, $6 \%$ of total value of houses sold is $\$ 18.4$ billions. These two figures are also roughly consistent with the total revenue of real estate brokerage firms reported by the Economic Census. For example, in 1992, total revenues of residential real estate firms is equal to $\$ 20$ billions. See US Department of Commerce (1995), Table 1.

${ }^{68} 8.2$ billion dollars in 1990 is roughly 0.16 percent of GDP.

${ }^{69}$ For example, the estimate in column 2 is the sum of social losses for cities where the productivity of realtors is lower than in Athens, and is based on the assumption that there are no social losses in cities where the productivity of realtors is equal to or higher than the productivity of realtors in Athens.
} 
column 2 to column 5, the estimated social losses from entry decline. If we use the median city (Pittsburgh, PA) as the benchmark, the social loss from entry in 1990 was 2.6 billion dollars. Our most conservative estimate, which uses Des Moines, Iowa as the benchmark city (column $5)$, indicates that the social loss from entry was 1.2 billion dollars.

Finally, in the bottom row, we report estimates of the excess number of brokers. Excess entry in city $j$ is defined as the difference between actual number of brokers in $j$ and the number of brokers that would exist in the benchmark city, if city $j$ and the benchmark city had the same size. ${ }^{70}$ If we use the median city as the benchmark (column 4), our estimates suggest that the excess number of realtors in 1990 was 161 thousand, or about a quarter of the total. The most conservative estimate in column 5 suggests that there was an excess 63 thousand realtors, or about $8 \%$ of the total.

\section{Conclusion}

This paper exploits the unique institutional characteristics of the US residential real-estate market to measure the extent of socially wasteful entry by real-estate agents into markets with high housing prices. We show that under the following three assumptions: (1) commission rates are fixed; (2) there is relatively free-entry into the real-estate business; and (3) it does not take more work to match buyers and sellers in cities where housing is more expensive, then higher commissions for each housing transaction in a high housing cost city will be fully dissipated through entry and wasteful prospecting activities. Therefore, our main empirical test is that the productivity of an average realtor in city with high property prices will be lower than in cities where housing is cheaper.

The empirical evidence confirms this prediction. In our most robust estimates that control for fixed differences in the difficulty of matching buyers and sellers across cities, we find that

\footnotetext{
${ }^{70}$ Specifically, excess entry is $b_{j}-\left(N_{j} *\left(b_{\text {benchmark }} / N_{\text {benchmark }}\right)\right)$, where $N_{j}$ is the total number of workers in city $j$.
} 
roughly two-thirds to three-quarters of the higher commissions in a city where the price of land has increased is dissipated by socially wasteful entry. In turn, we find that an average real-estate broker in a high-priced city is no better off than her counterpart in a city with cheaper housing. The outcome of a fixed commission is thus truly tragic: real-estate agents are no better off in cities where housing prices have increased, yet home-owners and home-sellers are clearly worse off.

The fact that a one percent increase in housing costs translates into a three-quarters of a percent drop in productivity, rather than a one percent decline, may simply reflect higher business costs in these cities. ${ }^{71}$ In addition, we can not completely rule out the argument that the lower number of sales per agent in expensive cities may reflect unmeasured differences in the quality of services provided by brokers. We provide four pieces of evidence on this point. First we show that our results hold up when controlling for permanent characteristics of cities and time varying characteristics of housing. Second, we show that the results do not change when we measure the effect of changes in housing prices that are entirely due to changes in the price of land. Third, we show that by one measure - average time on the market - it is easier, not more difficult, to match buyers and sellers in cities with more expensive housing. Fourth, we show that there is a weak relationship between the average number of houses visited by a home-buyer and the average price of housing in a city.

If our interpretation is correct, then the higher commission fees in more expensive cities are dissipated by excessive entry of brokers. What is striking about this story is that increases in housing prices raise commission fees paid by consumers, but do not raise brokers' profits. In this sense, this story is different from the standard analysis of welfare losses due to a monopoly. ${ }^{72}$ Increases in housing prices translate into pure economic losses, as brokers are not made better off, while consumer are made worse off.

Finally, we want to be clear about the message of this paper. First, we do not mean to

\footnotetext{
${ }^{71}$ Alternatively, it may indicate that commission rates are in fact be lower in high housing cost cities.

${ }^{72}$ Our argument, however, is exactly the same as Posner's (1975), who argued that monopoly rents should be counted in the costs of a monopoly.
} 
imply that restricting entry in the real-estate brokerage industry would necessarily reduce social losses. If one were to restrict entry into the real-estate brokerage industry, we can easily imagine a scenario in which the large profits from being a realtor in a high housing cost cities are dissipated through lobbying by agents attempting to become realtors. It may be possible to address this problem by auctioning real-estate brokerage licenses, but the point is that the mechanism that one uses to restrict entry is critically important. Second, our claim is not that free entry is generally socially wasteful. Clearly, it depends on the extent to which competition lowers prices and improves quality, on the one hand, and the extent to which entry spreads output over more producers, on the other hand. In an industry where demand is relatively price elastic, it is likely that entry will be socially beneficial. Ultimately, however, whether entry is beneficial is an empirical matter, and our hope is that this paper will prompt others to go out and uncover evidence of the net social gains from entry into other settings. 


\section{Bibliography}

Altonji, Joseph, Todd Elder, and Christopher Taber. "Selection on Observed and Unobserved Variables," Northwestern University mimeo (2001).

Arnold, M A. "The Principal Agent Relationship in Real Estate Brokerage Services," Journal of the American Real Estate and Urban Economics Association, 20, 89-106 (1992)

Berry, Steve and Joel Waldfogel. "Do Mergers Increase Product Variety: Evidence from Radio Broadcasting," Quarterly Journal of Economics 116(3), 969-1007 (2001).

Berry, Steve and Joel Waldfogel. "Free Entry and Social Inefficiency in Radio Broadcasting," RAND Journal of Economics 30(3), 397-420 (1999).

Burke, Mary and Peyton Young. "Competition and Custom in Economic Contracts: A Case Study of Illinois Agriculture." American Economic Review 91(3), June 2001, 559-73.

Carney, Michael "Real Estate Brokerage Commission rates: Price Fixing in Home Brokerage" PhD Dissertation, UCLA, 1981

Crockett, J H. "Competition and Efficiency in Transacting: The Case of Residential Real Estate Brokerage" Journal of the American Real Estate and Urban Economics Association vol 10 209-227 (1982)

Dixit, Avinash and Joseph Stiglitz. "Monopolistic Competition and Optimum Product Diversity," American Economic Review 67, 297-308 (1977).

Federal Trade Commission. The Residential Real Estate Brokerage Industry. Washington, DC: FTC, 1983.

Genesove, David and Christopher Mayer "Loss Aversion and Seller Behavior: Evidence from the Housing Market", Quarterly Journal of Economics vol 116 1233-1260 (2001).

Goolsby, W C and B J Childs "Brokerage Firm Competition in Real Estate Commission Rates" The Journal of Real Estate Research 3 (1989)

Hopkins, Tom. How to Master the Art of Listing \& Selling Real Estate. Englewood Cliffs, NJ: Prentice Hall, 1991.

Kennedy, Danielle and Warren Jamison. How to List and Sell Real Estate in the 21st Century. Upper Saddle River, NJ: Prentice Hall (1999).

Mankiw, N. Gregory, and Michael Whinston. "Free Entry and Social Inefficiency," Rand Journal of Economics 17(1), Spring 1986, 45-58.

Moretti, Enrico. "Estimating the Social Return to Education: Evidence from Longitudinal and Cross-Sectional Data" Center for Labor Economics, University of California, Berkeley, Working Paper No. 22 (1999)

Owen, B. "Kickbacks, Specialization, Price Fixing and Efficiency in Residential Real Estate Markets" Stanford Law Review 29 931-967 (1977) 
Posner, Richard (1975). "The Social Costs of Monopoly and Regulation," Journal of Political Economy 83, 807-827.

Sirmans, C F and G Turnbull "Brokerage Pricing under Competition", Journal of Urban Economics 41 102-117 (1997)

Spence, Michael. "Product Selection, Fixed Costs, and Monopolistic Competition," Review of Economic Studies 43, 217-236 (1976).

Spence, Michael. "Product Differentiation and Welfare," American Economic Review 66, 407-414 (1976).

Stein, Jeremy. "Prices and Trading Volume in the Housing Market: A Model with Downpayment Constraints," Quarterly Journal of Economics, 60, 379-406 (1995).

Tayler, Joan. How Real Estate Agents Earn Big! San Francisco: Mansion Press, 1997.

Turnbull, G. "Real Estate Brokers, Non price Competition and the Housing Market" Real Estate Economics 24 293-316 (1996)

US Department of Commerce "1992 Census of Financial, Insurance, Real-Estate Industries" (1995)

Williams "Agency and Brokerage of Real Assets in Competitive Equilibrium" The Review of Financial Studies, vol 11 239-280 (1998) 
endtable 
Figure 1: 1980-1990 Changes in Productivity of Real Estate Agents (Houses Sold in the City / Hours Worked) and Changes in Cost of Housing

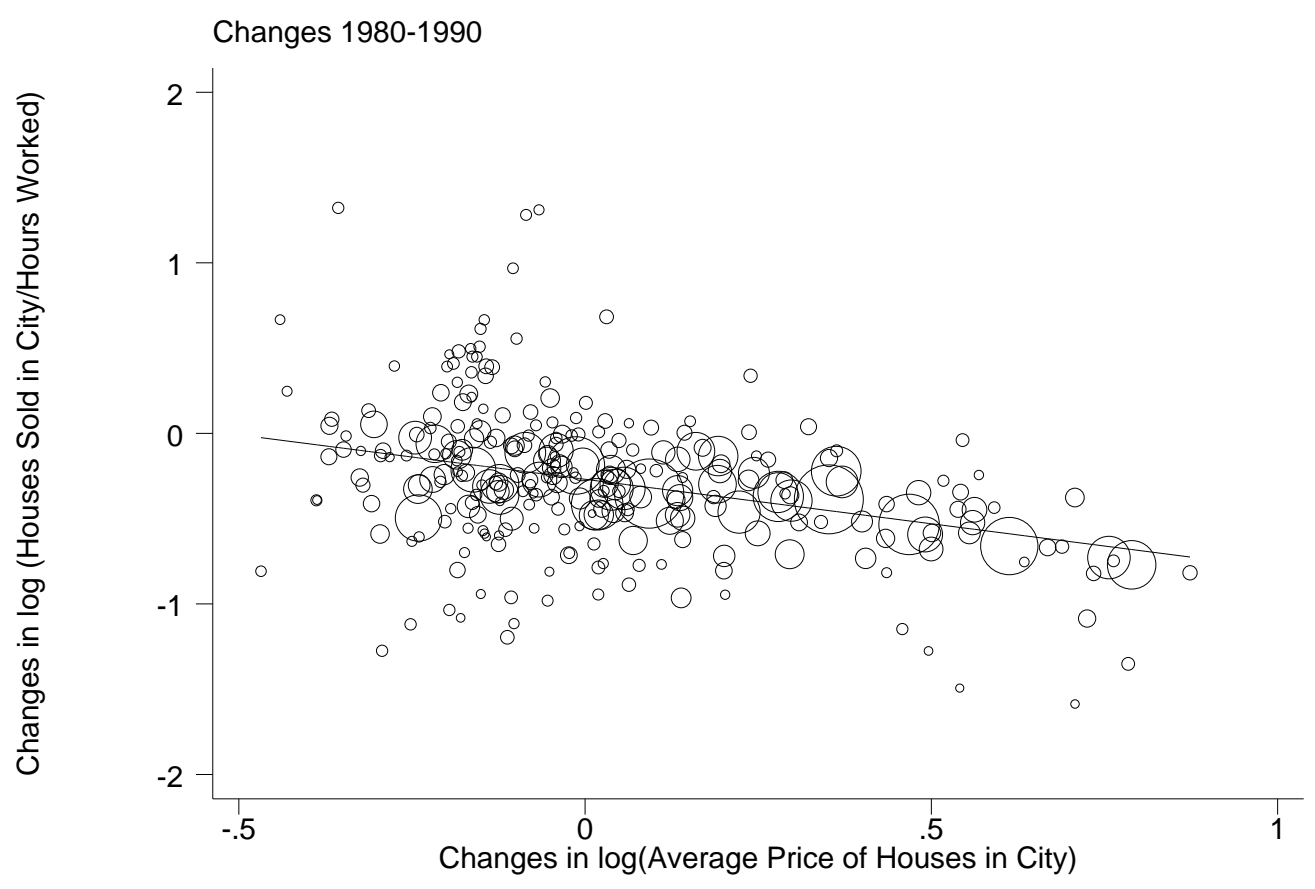

Note: Data are from the 1980 and 1990 Census of Population and Housing. 
Figure 2: Distribution of Commission Rates in U.S.

$$
\text { FTC Survey }(\mathrm{N}=934)
$$

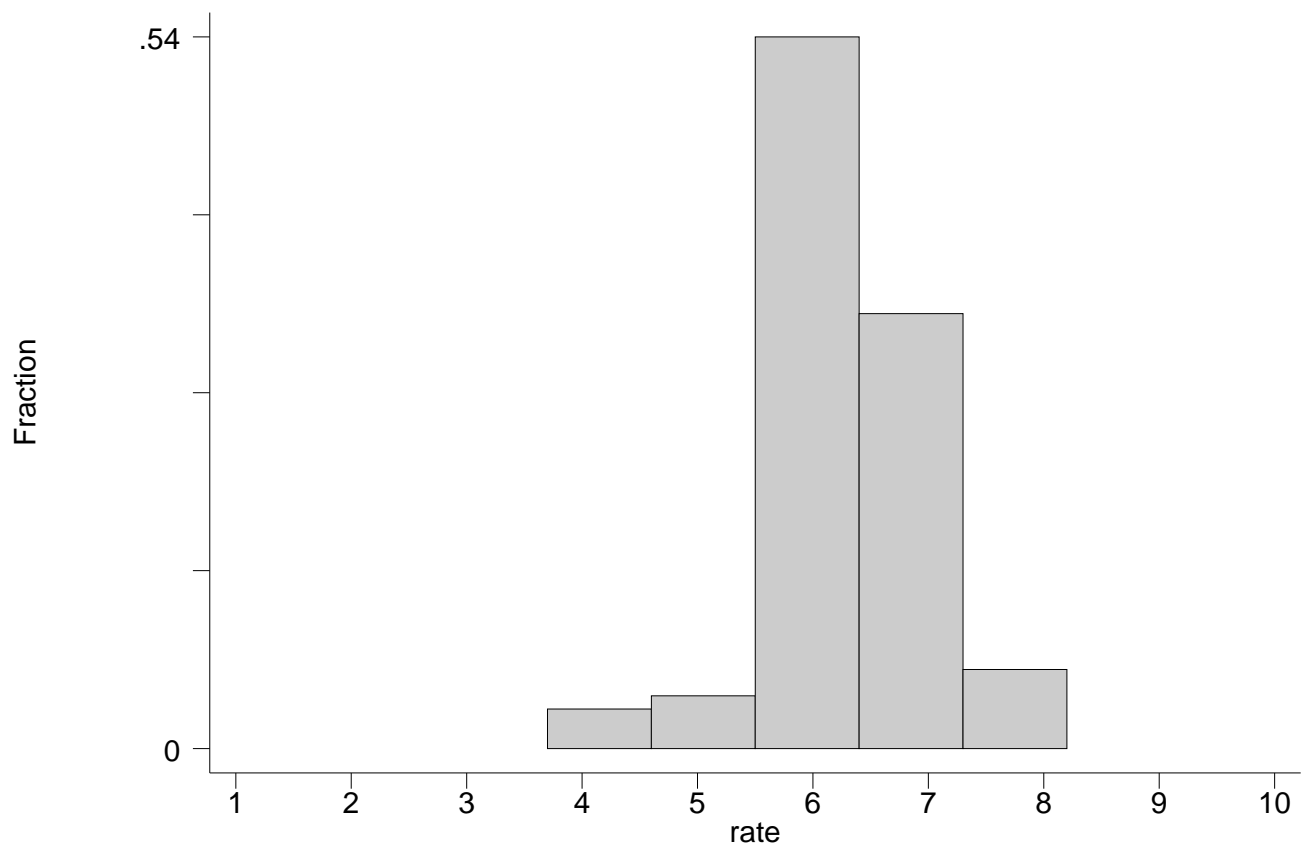

$$
\text { Settlement Documents }(\mathrm{N}=5000)
$$

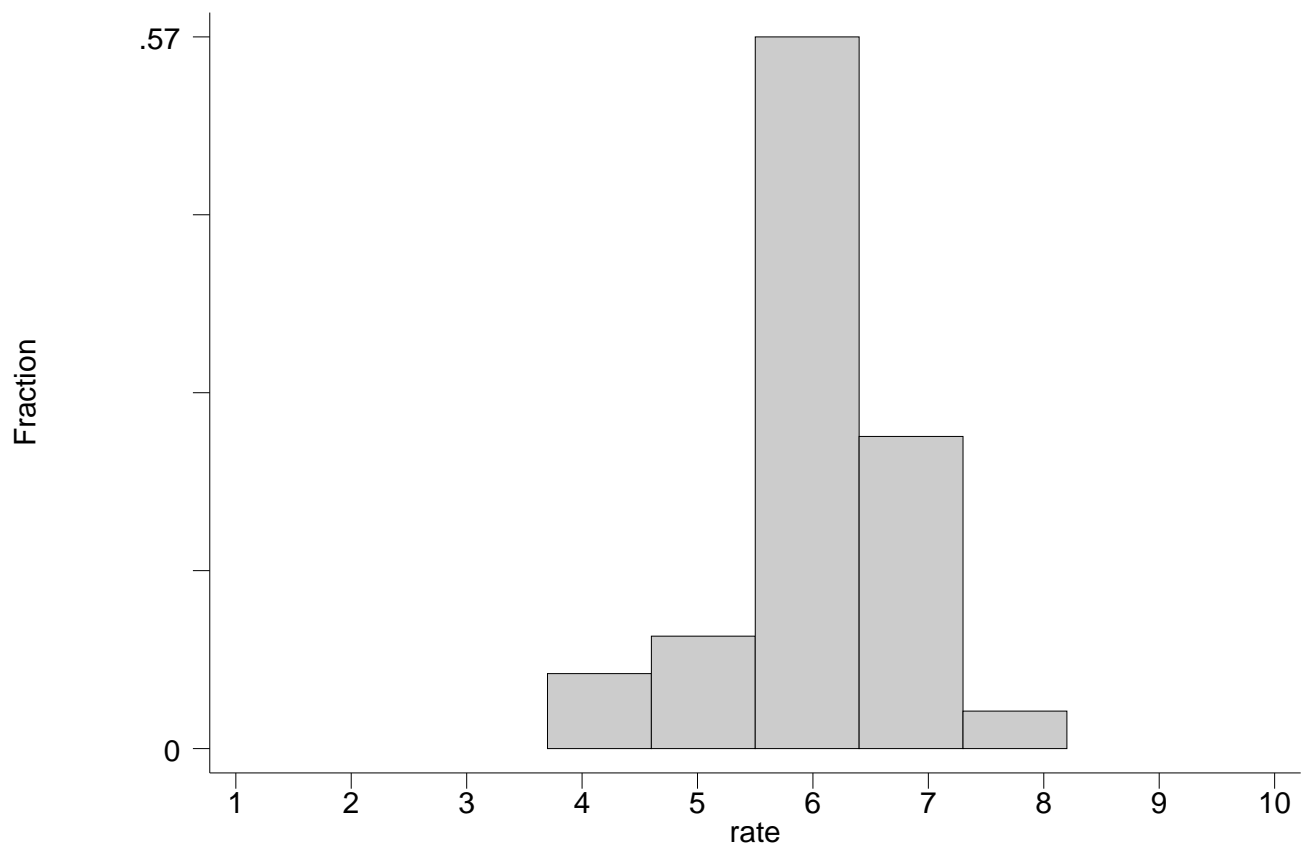


Figure 3: Distribution of Commission Rates in Four Cities

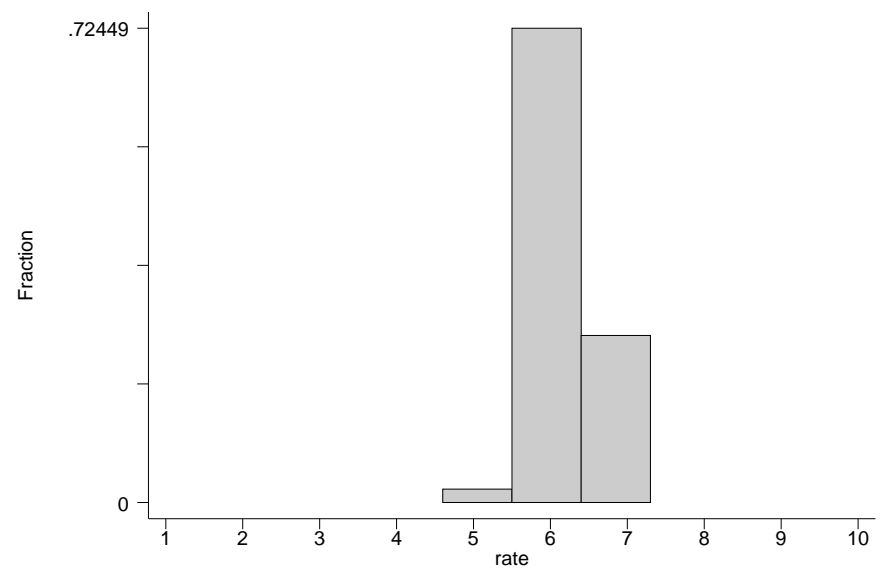

(a) Boston

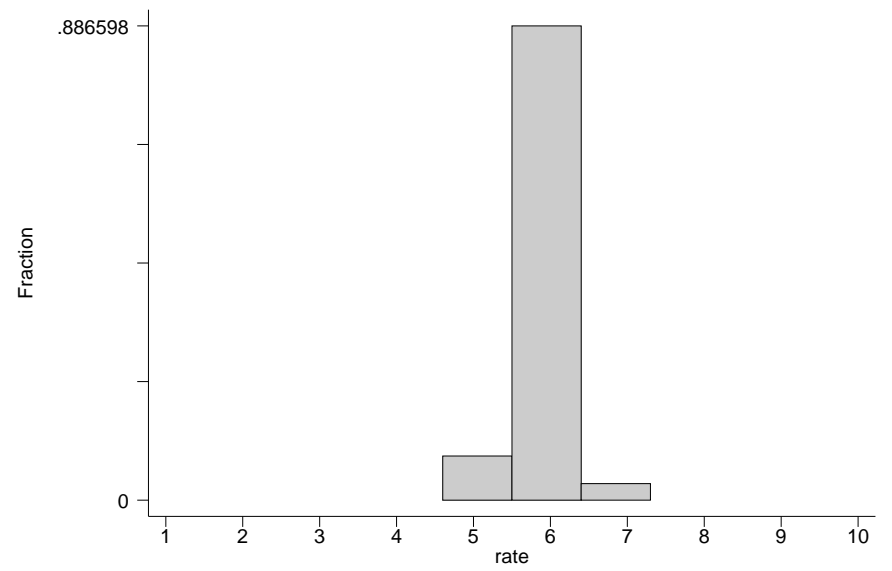

(c) Los Angeles

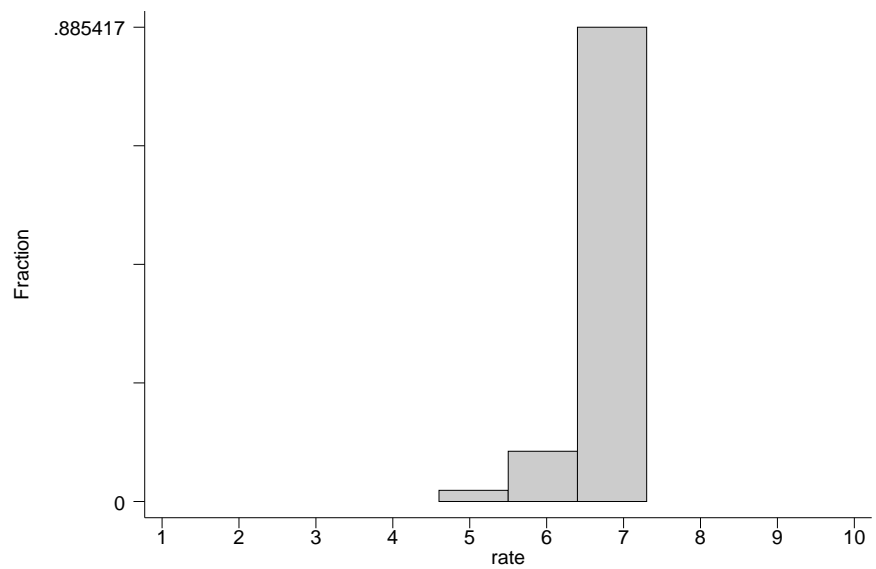

(b) Minneapolis/St. Paul

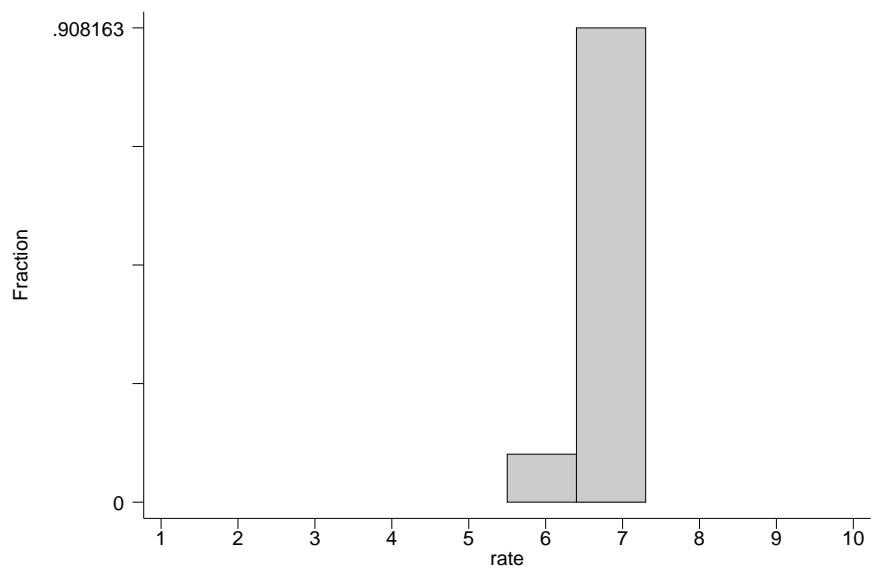

(d) Seattle 
Figure 4: Commission Rates and Price of Housing in the CEX

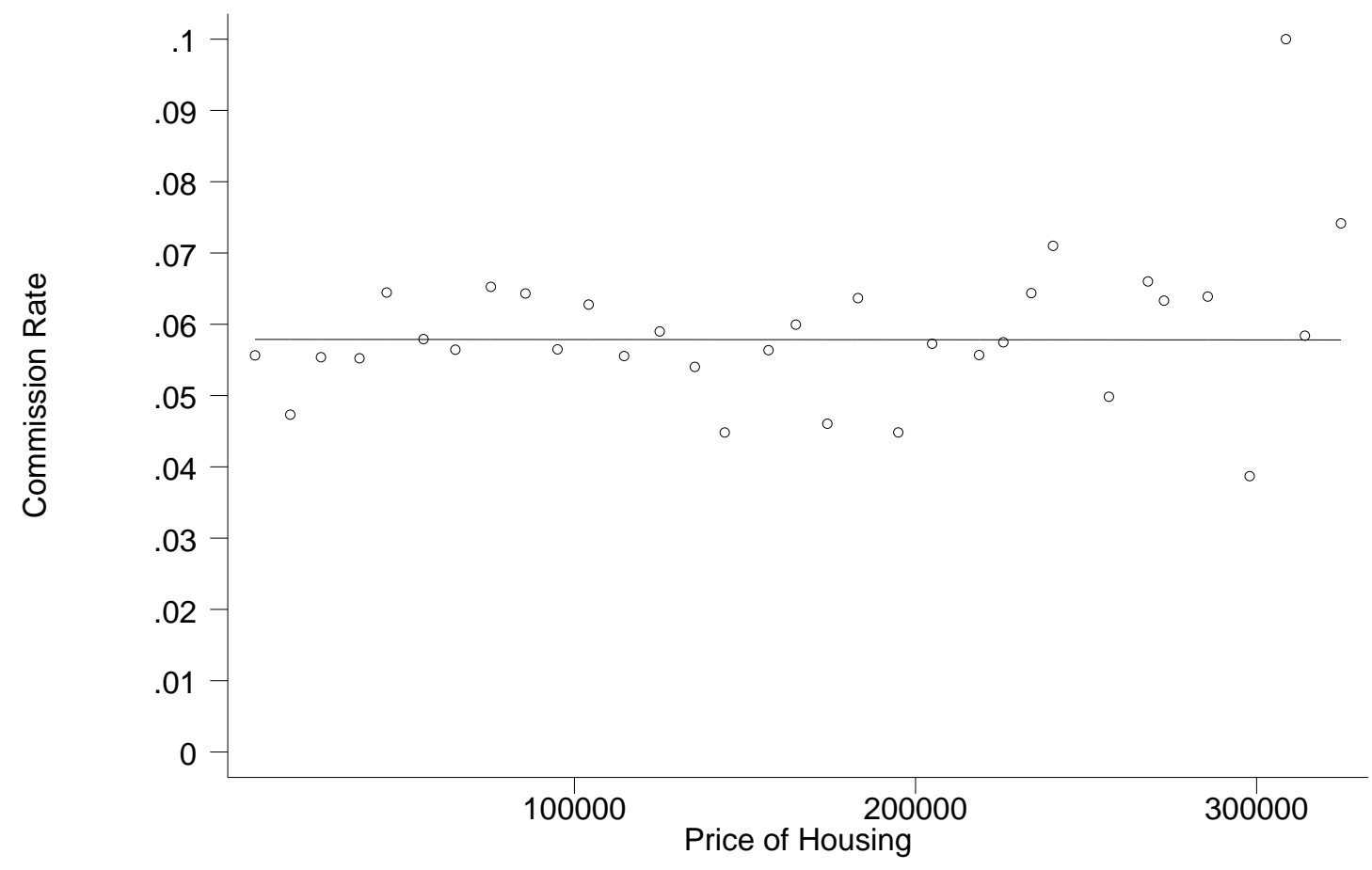

Notes: Each point in the Figure is the average commission rate within intervals in housing price $\$ 10,000$ wide. The superimposed fit is from an household level regression of commission rates on housing prices. $\mathrm{N}=406$. 
Figure 5: Percentage of Real Estate Agents in the Labor Force and Average Cost of Housing
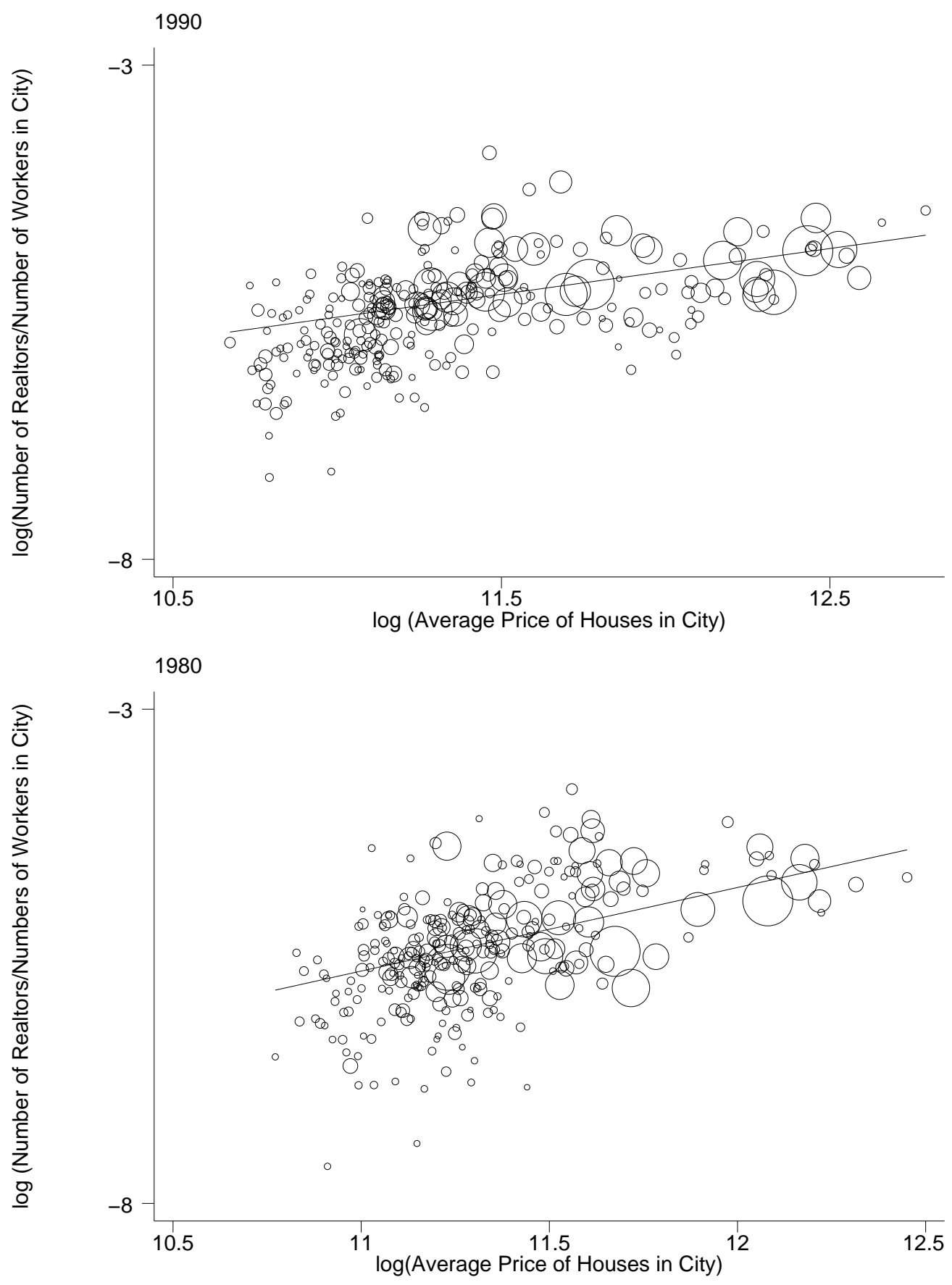

Notes: The top panels refers to 1990. The bottom panels refers to 1980. Data are from the Census of Population and Housing. 
Figure 6: 1980-1990 Changes in Percentage of Real Estate Agents in the Labor Force and Changes in Average Cost of Housing

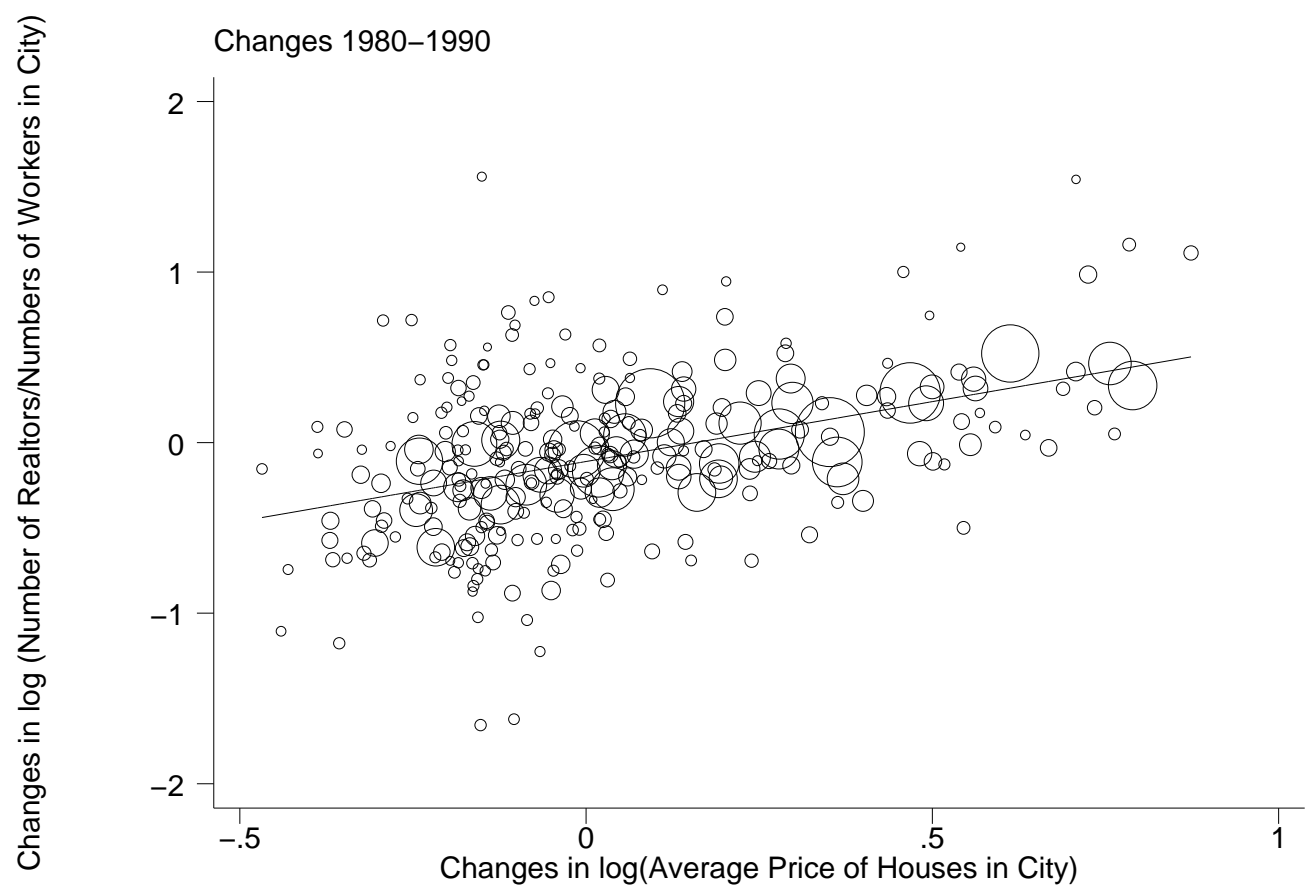

Notes: Data are from the 1980 and 1990 Census of Population and Housing. 
Figure 7: Productivity of Real Estate Agents (Houses Sold in the City / Hours Worked) and Cost of Housing
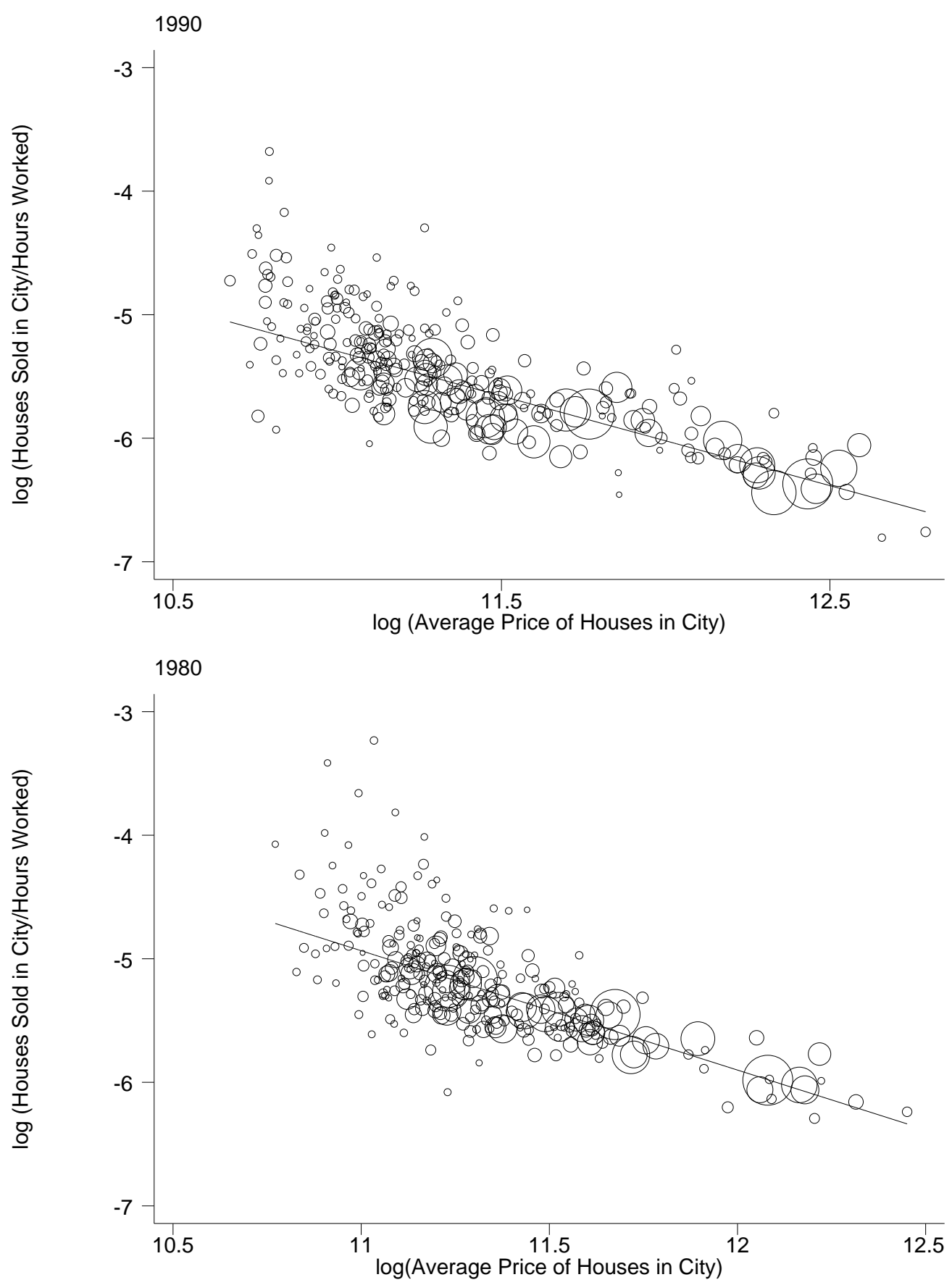

Notes: The top panels refers to 1990. The bottom refers to 1980. Data are from the Census of Population and Housing. 
Figure 8: Relationship between Total Earnings of Brokers and 6 percent of the Total Value of Homes Sold in 282 Cities in 1990

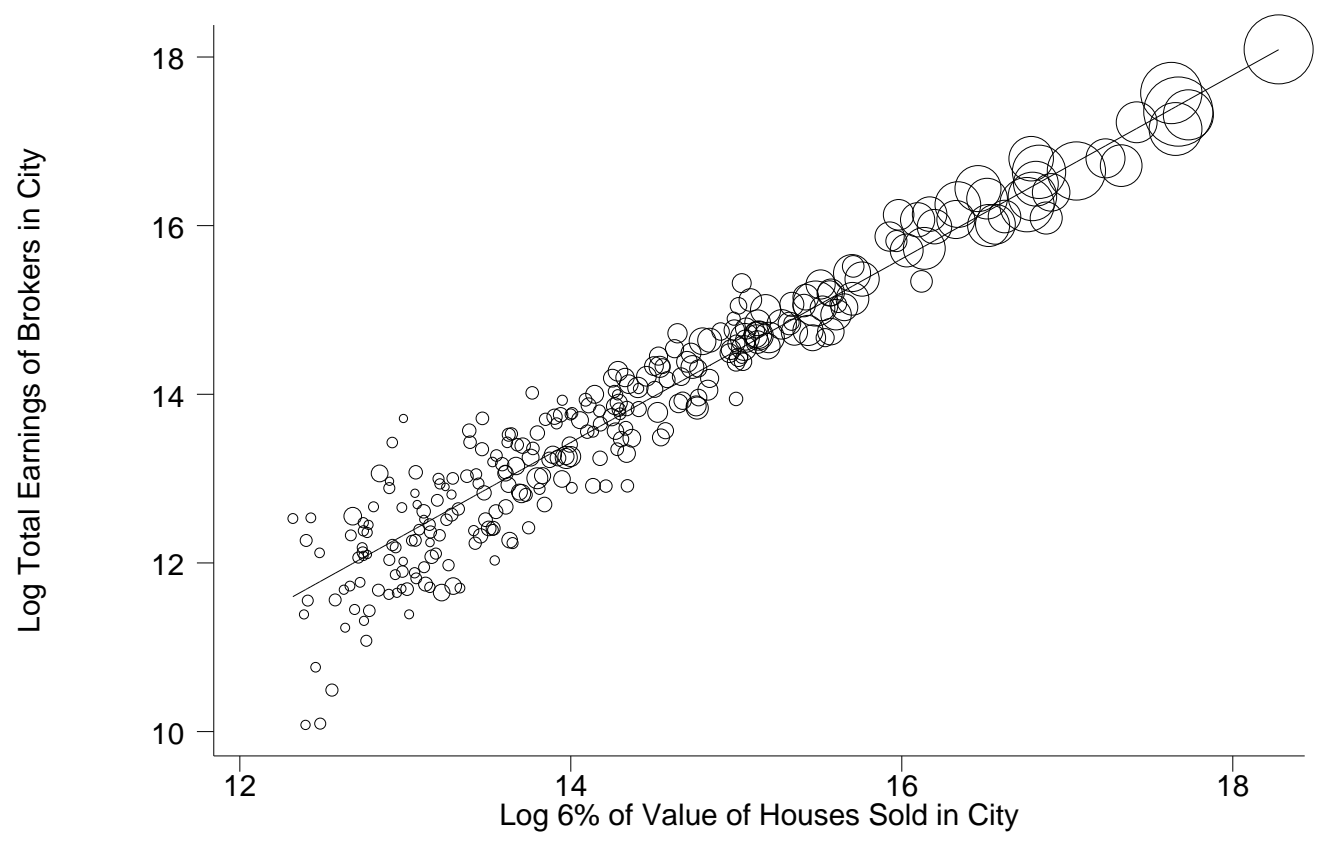

Notes: The $\mathrm{x}$-axis is the expected revenue of real-estate agents, calculated as 6 percent of the total value of homes sold in a city. The y-axis is the total value of brokers' earnings in the city (i.e. the sum of the earnings of all brokers in the city). If the commission rate for all transactions is 6 percent; and brokers' earnings comes exclusively from sales of residential home; then the sum of earnings reported by all brokers in a city should be exactly equal to 6 percent of the sum of the value of all home sales in the city. The solid line is the OLS fit, with an estimated slope equal 1.08 (0.01). Data are from the 1990 Census of Population and Housing. 
Figure 9: Average Earnings of Real Estate Agents and Average Price of Housing in 282 Cities in 1990

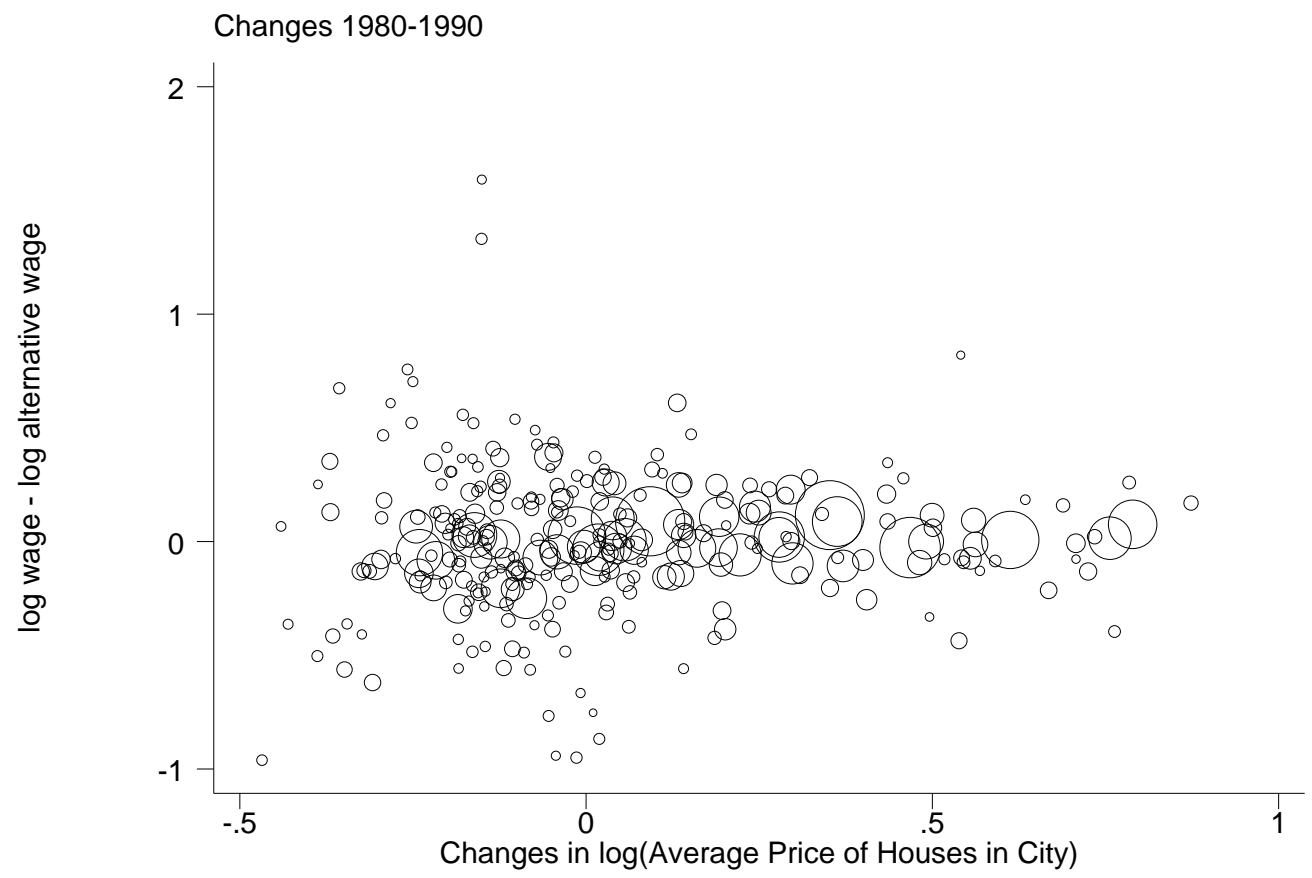

Notes: The y-axis is the log difference between average earnings in a city and brokers' reservation wage. The reservation wage of real estate agents is a weighted average of the wages of workers in all other occupations in the same city. We assign weights to individuals in the sample who are not brokers based on how similar their observable characteristics are to the observable characteristics of brokers. See text for details. 
Figure 10: Cost of Housing in 282 Metropolitan Areas and Vacancy time

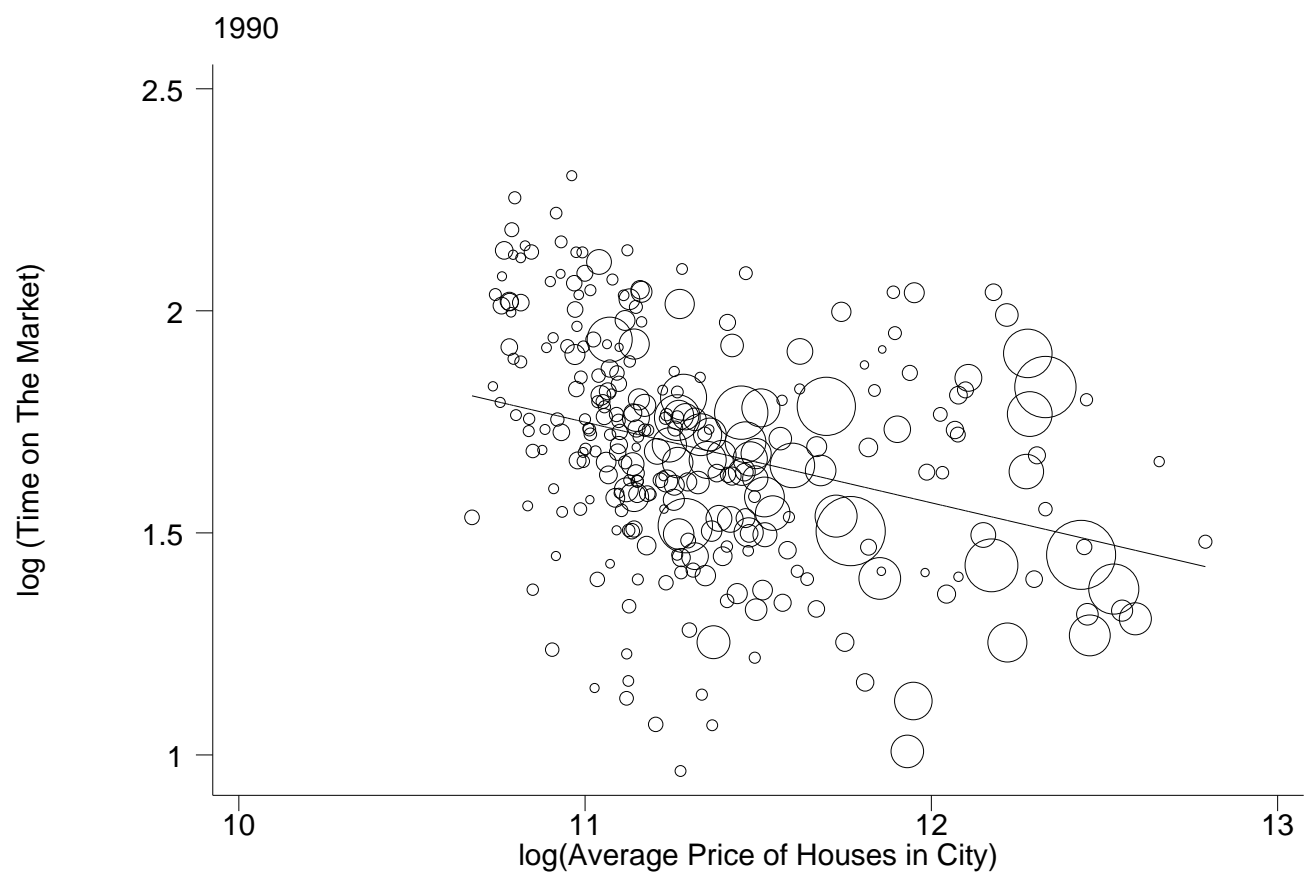

Notes: Data are from the 1990 Census of Population and Housing. 
Figure 11: The Effect of Housing Cost on the Number of Houses Looked at and Search Duration
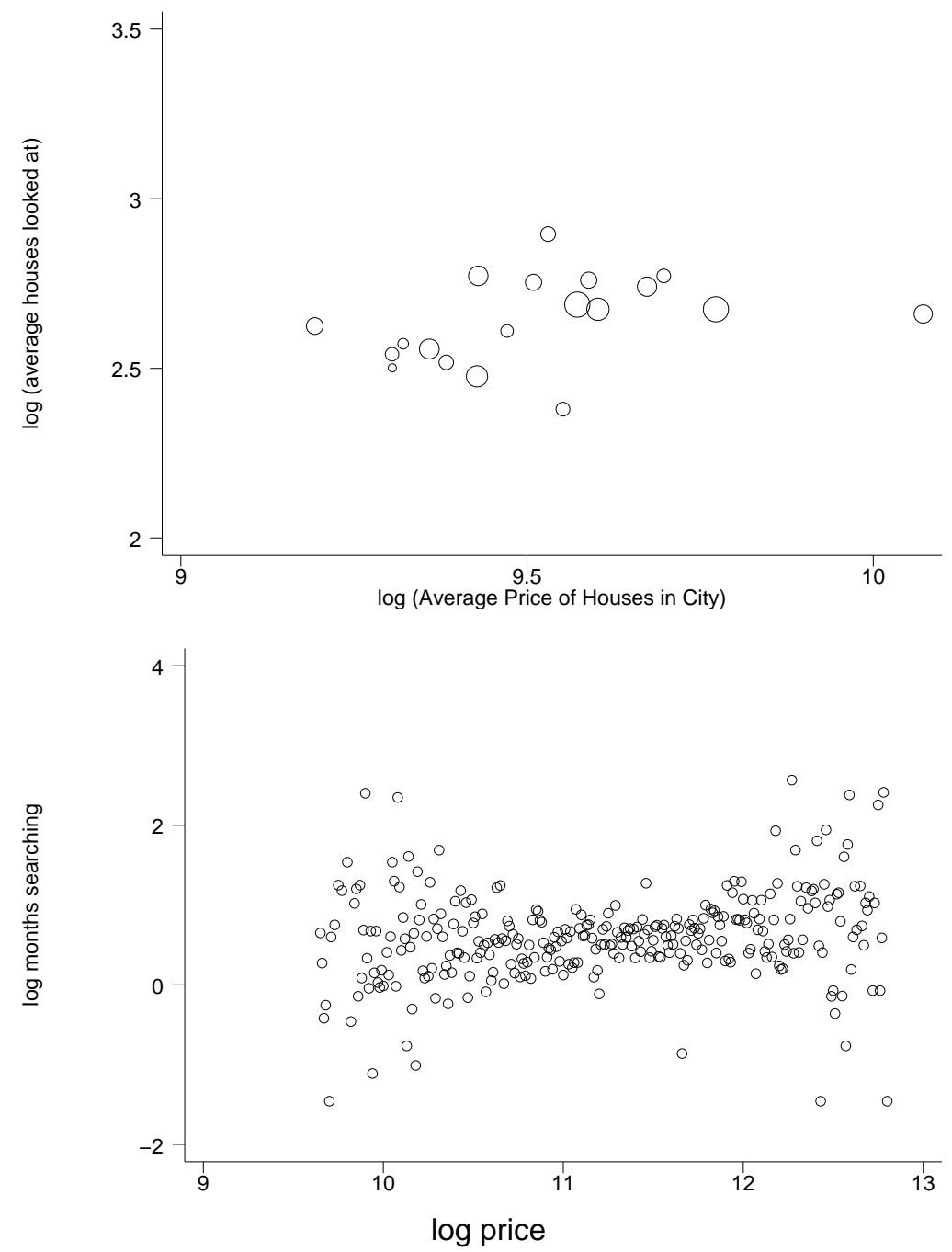

Notes: Top Panel: Data are from the 1997 Chicago Title and Trust Company Annual Survey of Recent Home Buyers, a representative sample of approximately 1,800 home buyers in 20 cities. The cities included in the survey are Atlanta; Boston; Chicago; Cleveland; Dallas/Fort Worth; Denver; Detroit; Houston; Los Angeles; Memphis; Miami; Minneapolis/St. Paul; New York City; Orange County; Orlando; Philadelphia; Phoenix; San Francisco; Seattle/Tacoma and Washington, D.C.

Bottom panel: Data are from the National Association of Realtors. Original data are at the household level $(\mathrm{N}=3839)$. Each point in the Figure is the average number of months spent by the respondents searching within narrow intervals in housing price. 
Table 1: Summary Statistics

\begin{tabular}{lcc}
\hline \hline & 1990 & 1980 \\
& $(1)$ & $(2)$ \\
\hline Number of obs per city & $7,457.2$ & $5,288.7$ \\
Number of realtors & 137.78 & 112.0 \\
Hours worked by realtors & $232,814.3$ & $181,503.2$ \\
Number of houses sold & 708.3 & 768.2 \\
Productivity & .004 & .005 \\
Log reservation wage & 2.33 & 2.31 \\
Price of houses & $94,142.3$ & $85,826.7$ \\
Age of house & 26.9 & 25.3 \\
Number of bedrooms & 2.56 & 2.50 \\
One family house & .73 & .73 \\
Condominium & .03 & .02 \\
Fraction renters in city & .35 & .33 \\
Months on the market (vacant homes) & 7.7 & 5 \\
\hline
\end{tabular}

Notes: Date are from the 1990 and 1980 Census of Population and Housing. There are 282 metropolitan areas. Prices are in 1990 dollars. Productivity is defined as number of houses sold in a city divided by number of hours worked by realtors. 
Table 2: Expensive and Affordable Cities

\begin{tabular}{|c|c|c|c|}
\hline Rank & 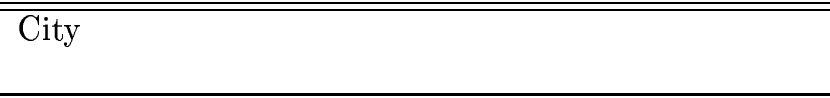 & $\begin{array}{c}\text { Average } \\
\text { Cost } \\
\end{array}$ & $\begin{array}{c}\log \\
\text { Productivity }\end{array}$ \\
\hline & Ten Least Expensive & & \\
\hline 1. & $\overline{\text { MCALLEN-EDINBURG-MISSION,TX }}$ & 43191.7 & -4.75 \\
\hline 2. & ODESSA, TX & 45884.3 & -5.40 \\
\hline 3. & STEUBENVILLE-WEIRTON, OH-WV & 46205.1 & -4.50 \\
\hline 4. & LAREDO, TX & 46856.2 & -4.30 \\
\hline 5. & BROWNSVILLE-HARLINGEN, TX & 47037.1 & -5.85 \\
\hline 6. & PINE BLUFF, AR & 47099.4 & -4.35 \\
\hline 7. & JOHNSTOWN, PA & 47401.3 & -5.23 \\
\hline 8. & WHEELING, WV-OH & 48102.8 & -4.89 \\
\hline 9. & HUNTINGTON-ASHLAND, WV-KY-OH & 48110.2 & -4.76 \\
\hline \multirow[t]{2}{*}{10.} & BEAUMONT-PORT ARTHUR, TX & 48154.0 & -4.62 \\
\hline & Ten Most Expensive & & \\
\hline 273. & 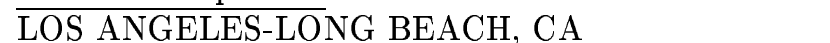 & 250836.0 & -6.37 \\
\hline 274. & SANTA BARBARA-SANTA MARIA-LOMPOC, CA & 253086.7 & -6.28 \\
\hline 275. & SANTA CRUZ, CA & 254757.5 & -6.07 \\
\hline 276. & OXNARD-VENTURA, CA & 255392.3 & -6.15 \\
\hline 277. & ANAHEIM-SANTA ANA, CA & 257170.8 & -6.40 \\
\hline 278. & SAN FRANCISCO, CA & 275669.8 & -6.24 \\
\hline 279. & HONOLULU, HI & 282350.8 & -6.43 \\
\hline 280. & SAN JOSE, CA & 293341.2 & -6.05 \\
\hline 281. & NORWALK, CT & 314269.5 & -6.80 \\
\hline \multirow[t]{3}{*}{282.} & STAMFORD, CT & 359127.6 & -6.75 \\
\hline & & $\begin{array}{l}\text { Change in log } \\
\text { Average Cost }\end{array}$ & $\begin{array}{l}\text { Change in log } \\
\text { Productivity }\end{array}$ \\
\hline & Ten Smallest Changes & & \\
\hline 1. & $\overline{\text { LAFAYETTE, LA }}$ & -.37 & -.80 \\
\hline 2. & RICHLAND-KENNEWICK-PASCO, WA & -35 & .66 \\
\hline 3. & WATERLOO-CEDAR FALLS, IA & -.34 & .24 \\
\hline 4. & DECATOUR, IL & -.32 & -.39 \\
\hline 5. & BILLINGS, MT & -.32 & -.39 \\
\hline 6. & DAVENPORT-ROCK ISLAND IA-IL & -.30 & -.13 \\
\hline 7. & PEORIA, IL & -.30 & .04 \\
\hline 8. & EUGENE-SPRINGFIELD, OR & -.30 & .08 \\
\hline 9. & PROVO-OREM, UT & -.29 & 1.32 \\
\hline \multirow[t]{2}{*}{10} & CHARLESTON, WV & -.29 & -.09 \\
\hline & Ten Largest Changes & & \\
\hline 272. & NEW YORK, NY & .84 & -.66 \\
\hline 273. & POUGHKEEPSIE, NY & .95 & -.66 \\
\hline 274. & LOWELL, MA-NH & .99 & -.66 \\
\hline 275. & SPRINGFIELD, MA & 1.02 & -.37 \\
\hline 276. & FALL RIVER, MA-RI & 1.02 & -1.58 \\
\hline 277. & WORCESTER, MA & 1.06 & -1.08 \\
\hline 278. & BOSTON, MA & 1.13 & -.72 \\
\hline 279. & NEW BEDFORD, MA & 1.14 & -.74 \\
\hline 280. & JERSEY CITY, NJ & 1.19 & -1.35 \\
\hline 281. & NASSAU-SUFFOLK, NY & 1.20 & -.77 \\
\hline 282. & LAWRENCE-HAVERHILL, MA-NH & 1.39 & -.81 \\
\hline
\end{tabular}

Notes: prices are in 1990 dollars. Productivity is number of sales per hour worked. Average cost is the average price of houses in 1989. Change in average cost is the change in average price of houses between 1979 and 1989. 
Table 3: The Correlation Between Housing Prices and Brokers' Observable Characteristics

\begin{tabular}{|c|c|c|c|c|}
\hline & $\begin{array}{c}\text { Mean } \\
\text { in } 1990 \\
(1)\end{array}$ & $\begin{array}{c}1990 \\
(2)\end{array}$ & $\begin{array}{c}1980 \\
(3)\end{array}$ & $\begin{array}{c}\text { Changes } \\
1980-1990 \\
(4)\end{array}$ \\
\hline College or Some College & 0.78 & $\begin{array}{c}0.06 \\
(0.01)\end{array}$ & $\begin{array}{c}0.15 \\
(0.01)\end{array}$ & $\begin{array}{c}0.00 \\
(0.02)\end{array}$ \\
\hline Years of Schooling & 14.2 & $\begin{array}{c}0.49 \\
(0.05)\end{array}$ & $\begin{array}{c}0.70 \\
(0.08)\end{array}$ & $\begin{array}{c}0.21 \\
(0.10)\end{array}$ \\
\hline Part-Time & 0.14 & $\begin{array}{c}-0.03 \\
(0.01)\end{array}$ & $\begin{array}{l}-0.06 \\
(0.01)\end{array}$ & $\begin{array}{c}-0.00 \\
(0.01)\end{array}$ \\
\hline Female & 0.53 & $\begin{array}{c}-0.02 \\
(0.01)\end{array}$ & $\begin{array}{l}-0.06 \\
(0.01)\end{array}$ & $\begin{array}{l}-0.01 \\
(0.02)\end{array}$ \\
\hline Black & 0.03 & $\begin{array}{c}0.01 \\
(0.00)\end{array}$ & $\begin{array}{c}0.01 \\
(0.00)\end{array}$ & $\begin{array}{c}0.00 \\
(0.00)\end{array}$ \\
\hline Age & 44.7 & $\begin{array}{l}-1.51 \\
(0.30)\end{array}$ & $\begin{array}{c}0.30 \\
(0.42)\end{array}$ & $\begin{array}{c}-3.40 \\
(0.62)\end{array}$ \\
\hline
\end{tabular}

Notes: Standard errors in parenthesis. Entries in column 1 are 1990 averages. Entries in column 2 to 4 are the OLS coefficients on housing prices. The sample includes only real estate brokers. College or Some College is a dummy equal 1 if years of schooling is 13 or more. Part time is a dummy equal 1 if the brokers works less than 30 hours a week. All models are weighted by city population. $\mathrm{N}=282$. 
Table 4: Effect of Average Price of Houses on the Relative Wage of Brokers

\begin{tabular}{lccc}
\hline \hline & 1990 & 1980 & Changes \\
& & & $1980-1990$ \\
& $(1)$ & $(2)$ & $(3)$ \\
\hline Cost of Houses & 0.079 & 0.163 & 0.064 \\
& $(0.019)$ & $(0.027)$ & $(0.041)$ \\
R-squared & 0.05 & 0.10 & 0.01 \\
\hline
\end{tabular}

Notes: Standard errors in parenthesis. The dependent variable is the log difference between average earnings of brokers and brokers' reservation wage. The reservation wage is a weighted average of the wages of workers in non-real estate occupations in the same city. We assign weights to individuals in the sample who are not brokers based on how similar their observable characteristics are to the observable characteristics of brokers. See text for details. N=282. 
Table 5: Effect of Average Price of Houses on the Productivity of Brokers Controlling for Housing Quality

\begin{tabular}{|c|c|c|c|c|}
\hline & \multirow{4}{*}{$\begin{array}{c}\text { OLS } \\
\text { Changes } \\
1980-1990 \\
(1)\end{array}$} & \multirow{4}{*}{$\begin{array}{c}\text { OLS } \\
\text { Changes } \\
1980-1990 \\
(2)\end{array}$} & \multicolumn{2}{|c|}{$\overline{\mathrm{IIV}}$} \\
\hline & & & Changes & Changes \\
\hline & & & $1980-1990$ & $1980-1990$ \\
\hline & & & (3) & (4) \\
\hline \multirow[t]{2}{*}{ Cost of Houses } & -0.646 & -0.714 & -0.706 & -0.694 \\
\hline & $(0.069)$ & $(0.080)$ & $(0.091)$ & $(0.089)$ \\
\hline \multirow{2}{*}{ Average Age } & & 0.011 & 0.007 & 0.011 \\
\hline & & $(0.007)$ & $(0.008)$ & $(0.007)$ \\
\hline \multirow[t]{2}{*}{ Average Number of Bedrooms } & & 0.405 & 0.261 & 0.405 \\
\hline & & $(0.175)$ & $(0.213)$ & $(0.175)$ \\
\hline \multirow[t]{2}{*}{ Percent One Family Homes } & & 0.875 & 1.428 & 0.856 \\
\hline & & $(0.328)$ & $(0.398)$ & $(0.330)$ \\
\hline \multirow[t]{2}{*}{ Percent Condominium } & & -0.271 & -0.207 & -0.308 \\
\hline & & $(0.330)$ & $(0.374)$ & $(0.336)$ \\
\hline \multirow[t]{2}{*}{ Percent with Plumbing } & & -1.150 & -3.085 & -1.172 \\
\hline & & $(2.766)$ & $(4.266)$ & $(2.766)$ \\
\hline \multirow[t]{2}{*}{ Percent with Kitchen } & & 3.335 & 1.341 & 3.374 \\
\hline & & $(2.696)$ & $(3.641)$ & $(2.696)$ \\
\hline R-squared & 0.23 & 0.30 & & \\
\hline \multicolumn{5}{|l|}{ First Stage } \\
\hline$\overline{\text { Repeated Sales Price Index }}$ & & & 0.783 & \\
\hline \multirow[t]{2}{*}{ Census Price Index } & & & & 0.608 \\
\hline & & & & $(0.018)$ \\
\hline $\mathrm{N}$ & 282 & 282 & 119 & 282 \\
\hline
\end{tabular}

Notes: Standard errors in parenthesis. The dependent variable is log of total number of houses sold over total number of hours worked by real estate agents. The IV in column 3 is the OFHEO price index based on repeated sales. The IV in column 4 is a price index based on changes in prices of houses that existed both in 1980 and in 1990. See text for details. All models are weighted by city population. 
Table 6: Robustness Checks: Effect of Average Price of Houses on the Productivity of Brokers

\begin{tabular}{lccc}
\hline \hline & 1990 & 1980 & Changes \\
& & & $1980-1990$ \\
& $(1)$ & $(2)$ & $(3)$ \\
\hline 1) Base Case & -0.929 & -1.098 & -0.646 \\
& $(0.059)$ & $(0.049)$ & $(0.069)$ \\
2) Number of Bedrooms & -0.992 & -1.139 & -0.759 \\
& $(0.042)$ & $(0.048)$ & $(0.071)$ \\
3) Control for City Population & -0.883 & -1.089 & -0.745 \\
& $(0.045)$ & $(0.048)$ & $(0.083)$ \\
4) Control for Percentage Renters & -0.822 & -0.987 & -0.668 \\
& $(0.047)$ & $(0.059)$ & $(0.086)$ \\
5) Median Cost of Houses & -0.823 & -1.112 & -0.531 \\
& $(0.038)$ & $(0.056)$ & $(0.068)$ \\
6) Drop New York city & -0.900 & -1.088 & -0.689 \\
& $(0.041)$ & $(0.049)$ & $(0.073)$ \\
\hline
\end{tabular}

Notes: Standard errors in parenthesis. All models are weighted by city population. 
Table 7: Effect of Average Price of Houses on Vacancies

\begin{tabular}{lccc}
\hline \hline & 1990 & 1980 & Changes \\
& & & $1980-1990$ \\
& $(1)$ & $(2)$ & $(3)$ \\
\hline Cost of Houses & -0.181 & -0.483 & -0.224 \\
& $(0.025)$ & $(0.047)$ & $(0.058)$ \\
R-squared & 0.14 & 0.26 & 0.05 \\
\hline
\end{tabular}

Notes: Standard errors in parenthesis. The dependent variable is the log of the average monthly duration of vacancies in a city. Sample include all vacant houses. $\mathrm{N}=281$.

Table 8: Effect of Price of Houses on the Number of Houses Looked At and the Duration of Search

\begin{tabular}{|c|c|c|c|}
\hline & $\begin{array}{c}\text { Number of Houses } \\
\text { Looked At } \\
\text { (City Level) } \\
\text { (1) }\end{array}$ & $\begin{array}{r}\text { Dur } \\
\text { S } \\
\text { (House } \\
(2)\end{array}$ & $\begin{array}{l}\text { on of } \\
\text { rch } \\
\text { ld Level) } \\
(3)\end{array}$ \\
\hline Cost of Houses & $\begin{array}{c}0.135 \\
(0.099)\end{array}$ & $\begin{array}{c}0.127 \\
(0.032)\end{array}$ & $\begin{array}{c}0.102 \\
(0.039)\end{array}$ \\
\hline $\mathrm{N}$ & 20 & 3839 & 3069 \\
\hline R-squared & 0.21 & 0.04 & 0.03 \\
\hline
\end{tabular}

Notes: Standard errors in parenthesis. The dependent variable in column 1 is the log of the number of houses looked at. Data are from the 1997 Chicago Title and Trust Company Annual Survey of Recent Home Buyers, a representative sample of approximately 1,800 home buyers in 20 cities. The dependent variable in columns 2 and 3 is the log of the duration of housing search (in months). Data household level data from a survey collected by the National Association of Realtors. Both models include year effects. The model in column 2 also controls for age of the house and number of bedrooms. 


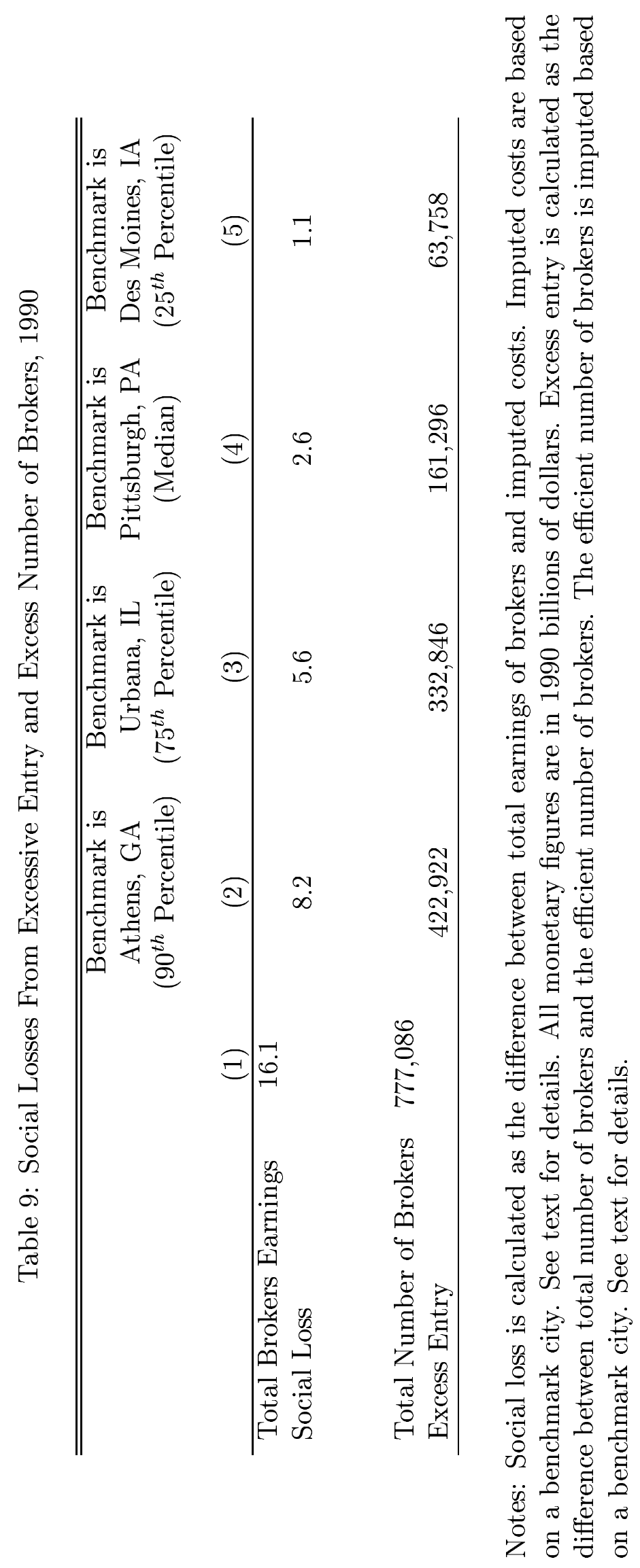


Table A1: Number of Active and Inactive Licensed Brokers by State

\begin{tabular}{lcc}
\hline \hline State & Active & Inactive \\
\hline Alabama & 19,599 & 4,435 \\
Alaska & 2,600 & 1000 \\
Arizona & 43,000 & 13,000 \\
Arkansas & 13,000 & 6,000 \\
California & 301,566 & \\
Colorado & 32,441 & 20,566 \\
Connecticut & 33,765 & \\
Delaware & 3,524 & 348 \\
DC & 7,047 & \\
Florida & 227,331 & 107,306 \\
Georgia & 37,837 & 15,235 \\
Hawaii & 14323 & 7,852 \\
Idaho & 5,007 & 3,639 \\
Illinois & 88,097 & 21,145 \\
Indiana & 43,635 & 19,200 \\
Iowa & 14,543 & 3,562 \\
Kansas & 13,900 & 3,000 \\
Kentucky & 19,340 & 2,345 \\
Louisiana & 28,804 & 6,584 \\
Maine & 5,974 & 2,622 \\
Maryland & 34,285 & 1,581 \\
Massachusetts & 150,736 & 24,324 \\
Michigan & 46,700 & 30,500 \\
Minnesota & 26,000 & \\
Mississippi & 8,474 & 3,453 \\
Missouri & 53,825 & 4,356 \\
Montana & 4,642 & 561 \\
Nebraska & 8,945 & 1,737 \\
Nevada & 6,327 & 3,930 \\
New Hampshire & 11,896 & \\
New Jersey & 82,200 & \\
New Mexico & 9,474 & 1,840 \\
New York & 127,047 & \\
North Carolina & 65,820 & \\
North Dakota & 2,325 & 100 \\
Ohio & 48,653 & \\
Oklahoma & 21,241 & 12,644 \\
Oregon & 14,731 & 1,652 \\
Pennsylvania & 46,789 & 57,354 \\
Rhode Island & 5,200 & \\
South Carolina & 20,922 & 1,620 \\
South Dakota & 3,165 & 1,702 \\
Tennessee & 21,980 & 13,240 \\
Texas & 154,564 & 22,965 \\
Utah & 9,316 & 7,884 \\
Vermont & 5,599 & \\
Virginia & 44,178 & 14,989 \\
Washington & 25,653 & 29,369 \\
West Virginia & 8,319 & \\
Wisconsin & 32,000 & \\
Wyoming & 2,322 & 1,505 \\
\hline & & \\
\hline
\end{tabular}

Source: Digest of Real Estate License Laws, 1987. 


\section{Appendix 1: Heterogenous Agents}

In this appendix we allow agents to differ by ability, which is referenced by an index $\mathrm{i}$, and is distributed uniformly from 0 to 1 . If person i decides to work outside the real estate sector, her wage will be given by $\mathrm{w}_{i}^{j}=w^{j}+\theta \cdot i$, where $\theta$ is a positive constant; high ability individuals (people with high i's) have higher wages. In turn, if she decides to become a real estate agent, then her fraction of the "market" is $\frac{i}{2 \cdot i_{\max } \cdot b^{j}-\left(b^{j}\right)^{2}}$, where $\mathrm{i}_{\max }$ is the ability index of the real-estate agent with the highest ability and, as before, $\mathrm{b}^{j}$ is the equilibrium number of brokers in city $\mathrm{j} \cdot\left(2 \cdot i_{\max } \cdot b^{j}-\left(b^{j}\right)^{2}\right.$ is the sum of $\mathrm{i}$ for all brokers, assuming that all individuals $\mathrm{i} \in\left[i_{\max }-b^{j}, i_{\max }\right]$ choose to become brokers.) This formulation assumes that individuals with high ability (high i's) capture a larger share of the real-estate market, but this share declines with the total number of people in the real estate sector $\left(\mathrm{b}^{j}\right)$. The earnings of individual $\mathrm{i}$ who decides to be a broker is thus the product of her share of the rents and total amount of rents available in the city: $\frac{i}{2 b^{j}-\left(b^{j}\right)^{2}} \cdot\left(c \cdot S \cdot P_{j}\right)$. We'll also assume that $w^{j}>\frac{c \cdot S \cdot P_{j}}{\left(b^{j}\right)^{2}}$ and $\frac{c \cdot S \cdot P_{j}}{2 b^{j}-\left(b^{j}\right)^{2}}<w^{j}+\theta$ : individuals at both extremes of the ability distribution (those with ability $\mathrm{i}=0$ and $\mathrm{i}=1$ ) will find it more profitable to work outside the real estate sector of the economy than to become a broker.

The equilibrium number of brokers is still determined by the condition that the wage must be the same in the two sectors, but now only for the marginal broker. This can be represented graphically by the intersection of lines RS and PS in figure A1, which plots the earnings in the two sectors against the ability index i. Schedule PS plots the wage in the non real estate sector as a function of $\mathrm{i}$, or $\mathrm{w}_{i}^{j}=w^{j}+\theta \cdot i$. Schedule RS plots the wage in the real estate sector as a function of $\mathrm{i}$, or $\frac{i}{2 b^{j}-\left(b^{j}\right)^{2}} \cdot\left(c \cdot S \cdot P_{j}\right)$. The assumption that $w^{j}>\frac{c \cdot S \cdot P_{j}}{\left(b^{j}\right)^{2}}$ and $\frac{c \cdot S \cdot P_{j}}{2 b^{j}-\left(b^{j}\right)^{2}}<w^{j}+\theta$ assures us that RS will lie below PS at $\mathrm{i}=0$ and below PS at $\mathrm{i}=1$. In equilibrium, all individuals with $i_{\max }-b^{j}<i<i_{\max }$ will choose to become brokers, and all individuals with $i<i_{\max }-b^{j}$ and $i>i_{\max }$ will choose to work outside real estate. Real-estate therefore attracts people from the "middle-class." The distribution of rents among brokers is highly skewed; agents with high i's get a large share of the real-estate market while those with low i's get a smaller share of the market. In this model, an increase in housing prices is represented by a backward shift in the RS schedule. This will increase less than in a model where all agents are homogeneous.

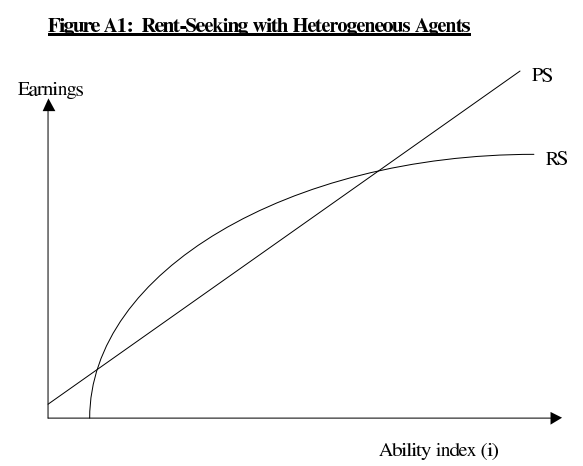

